\title{
Chapter 10 \\ Kelps and Environmental Changes \\ in Kongsfjorden: Stress Perception \\ and Responses
}

\author{
Kai Bischof, Christian Buschbaum, Stein Fredriksen, \\ Francisco J. L. Gordillo, Sandra Heinrich, Carlos Jiménez, Cornelius Lütz, \\ Markus Molis, Michael Y. Roleda, Max Schwanitz, and Christian Wiencke
}

\begin{abstract}
On rocky substrata along shallow water cold-temperate and Arctic coastlines, large brown seaweeds ("kelps") form structure- and organism-rich habitats of vast ecological significance. The distribution of these ecosystem engineers is largely controlled by the prevailing temperature, light regime and substrate availability, but can also be influenced by biotic interactions within the kelp communities. In Kongsfjorden, right in the transition of an Arctic to an Atlantic fjord system, the
\end{abstract}

K. Bischof $(\bowtie)$

Marine Botany, Faculty Biology/Chemistry, University of Bremen, Bremen, Germany

e-mail: kbischof@uni-bremen.de

C. Buschbaum

Alfred Wegener Institute, Helmholtz Centre for Polar and Marine Research,

Wadden Sea Station Sylt, List/Sylt, Germany

S. Fredriksen

Section for Aquatic Biology and Toxicology, Department of Biosciences, University of Oslo, Oslo, Norway

F. J. L. Gordillo · C. Jiménez

Department of Ecology and Geology, Faculty of Sciences, University of Málaga,

Málaga, Spain

S. Heinrich

University of Hamburg, Institute for Plant Sciences and Microbiology, Molecular

Plant Genetics, Hamburg, Germany

M. Molis · M. Schwanitz $\cdot$ C. Wiencke

Alfred Wegener Institute, Helmholtz Centre for Polar and Marine Research,

Bremerhaven, Germany

C. Lütz

Institute of Botany, Faculty of Biology, University of Innsbruck, Innsbruck, Austria

M. Y. Roleda

The Marine Science Institute, College of Science, University of the Philippines Diliman,

Quezon City, Philippines

H. Hop, C. Wiencke (eds.), The Ecosystem of Kongsfjorden, Svalbard,

Advances in Polar Ecology 2, https://doi.org/10.1007/978-3-319-46425-1_10 
aforementioned factors are likely to be altered as a consequence of regional and global environmental change. The drivers of change entail increasing surface irradiances of harmful ultraviolet B radiation due to stratospheric ozone depletion, and variations related to increased atmospheric carbon dioxide concentrations, such as increase in atmospheric and sea surface temperatures with their marked influence on sea ice formation and ocean acidification. Other factors potentially driving the Kongsfjorden system into change might be alterations of current and wind patterns resulting in the increased inflow of Atlantic waters into the bay (Atlantification), and increased precipitation, and terrestrial and glacial runoff, yielding an altered salinity regime and sediment discharge into the fjord with the potential impact of reducing light availability to marine photosynthesizers. Hence, this article is aiming to provide an overview on ecologically relevant abiotic and biotic factors influencing kelp distribution, and with the potential to eventually act as environmental stressors. We assess responses on different organisational levels of kelp by following the effects cascading from the initial sensing of the environment, signal transduction to gene expression, physiological reactions, changes in cellular ultrastructure and subsequent consequences for growth, reproduction and population biology for the different species of kelps present in Kongsfjorden.

Results synthesized from more than 20 years of seaweed research in Kongsfjorden point to the overall large adaptability of most of the kelp species being present in the system. Such species are to be expected to cope with the levels of increased ultraviolet radiation and temperature predicted in climate scenarios. However, susceptibility largely differs among the various life history stages of kelps, with the microscopic reproductive stages responding sensitively. Manipulation experiments conducted at ecologically relevant amplitudes, however, do not point to an inhibition of kelp viability and reproduction under proceeding change. Still, there is the important exception of an Arctic endemic kelp species, Laminaria solidungula, which will largely suffer from temperature increase. Thus, changes in kelp community composition, but also system productivity are to be expected. Subsequent to the synthesis of seaweed responses, this review concludes by identifying the major research gaps and priority topics for future kelp studies in Kongsfjorden.

Keywords Kelps $\cdot$ Seaweed $\cdot$ Physiology $\cdot$ Ecology

\subsection{General Introduction \& Objectives}

The rocky coastline of Kongsfjorden harbours a rich seaweed-dominated community. While the term "kelp" in a strict sense refers to seaweed species belonging to the phaeophyceaen order of Laminariales, we will here rather regard "kelps" as a functional entity by also including another large brown seaweed with a leaf-like phylloid present in Kongsfjorden: Saccorhiza dermatodea (de la Pylaie) J. Agardh, order Tilopteridales. 
Kelp species have a broad geographical distribution and are a major source of primary production and serve as an important biogenic habitat in coastal waters (Dayton 1985; Steneck et al. 2002). The three-dimensional underwater habitat formed by kelp harbours numerous associated species of both algae and animals and contributes significantly to the secondary production in shallow areas (Carlsen et al. 2007; Christie et al. 2009; Norderhaug and Christie 2011). Kelps are generally coldwater species and are limited by a maximum summer temperature of approximately $20{ }^{\circ} \mathrm{C}$, except for some occurrence in deep-water refugia in more tropical areas where the upper warm mixing layer is shallower than the light compensation depth thereby allowing kelp to grow in the cooler deeper water (Graham et al. 2007).

Kelps have a heteromorphic alternation of generations whereby two free-living phases are morphologically and ecologically distinct. The macroscopic and morphologically-complex sporophyte is diploid and undergoes sporogenesis. Meiospores are released, which settle and germinate into microscopic filamentous haploid male and female gametophytes. Further development of the microstages leads to spermatogenesis and oogenesis, respectively; fertilization and embryogenesis then give rise to the next generation of diploid sporophytes. Enormous numbers of these microscopic propagules are produced by kelps but only a small fraction directly forms sporophytes. These microstages serve as 'seed bank' for the next generation of the ecosystem-engineering macroscopic population. Changes in the viability of microscopic stages could be expected to have effects on recruitment and development of the macroscopic community (see Sect. 10.4.5). Physical stressors such as light, both quantity and quality, ultraviolet radiation (UVR) and temperature account for much of the mortality among spores, embryos and juveniles.

Basically, the seaweed flora of the European Arctic represents a depleted coldtemperate North Atlantic flora with a low degree of endemism. This is easily explained by the comparatively recent colonization history of Arctic coastlines, repopulated by seaweeds from the North Atlantic and also the North Pacific (Wulff et al. 2009) after the last glacial maximum approx. 18,000 years ago. During the glaciation period, all seaweed life became extinct from the Arctic due to ice coverage and exclusion of sunlight. Not before the onset of retreating ice masses, shorelines became accessible again to benthic colonizers and coastlines were repopulated by seaweeds following the northward migration of the ice edges (Wiencke and Bischof 2012). Thus, the recent establishment of an Arctic seaweed flora was fuelled from southern, cold-temperate populations, which gradually also adapted to thrive under the distinct high Arctic environmental conditions. As their conspecifics from lower latitudes, individuals of most Arctic species still display a comparatively broad tolerance range to changing environmental conditions. In contrast to Antarctica, the Arctic region is hardly geographically isolated, allowing for continuous connectivity between populations. Hence, and in addition to the recent event of repopulation, speciation processes have been limited. However, a re-evaluation of species connectivity and taxonomic identity for high Arctic kelp populations will be an important objective of future research.

Nowadays, researchers working at Kongsfjorden and other Svalbard fjords witness considerable changes in the physical, and commencing changes in the biotic 
environment. Most likely, these changes result from global climatic changes, shifting abiotic conditions within the fjord to a more boreal/Atlantic regime. These changes will impact the various biota to a different extent, and in order to predict the likely consequences of change to Kongsfjorden, the responses of kelps as ecosystem engineers need to be addressed urgently. Thus, the state of knowledge with respect to the Kongsfjorden kelp flora is presented and prominent gaps in knowledge are identified as a focus for future research.

\subsection{The Kelp Flora of Svalbard and Kongsfjorden}

In the cold-temperate areas along the coast of Norway, species like Laminaria hyperborea (Gunnerus) Foslie and Saccharina latissima (L.) C.E. Lane, C. Mayes, Druehl et G.W. Saunders (Fig. 10.1b) are the two dominating kelps in depths down to 25-30 m, while Laminaria digitata (Hudson) J.V. Lamouroux and Alaria esculenta (L.) Greville (Fig. 10.1a) are mostly limited to a narrow band in the transition zone between the littoral and the sublittoral (Rueness 1977). In the northernmost part of Norway, Saccorhiza dermatodea occurs frequently (Rueness 1977).

Laminaria gunneri Foslie is another species described from north Norway by Foslie (1884), but the current status of this species is questionable. On the western side of the Atlantic, Saccharina latissima is replaced by Saccharina longicruris (Bachelot de la Pylaie) Kuntze, a species with a hollow stipe. However, according to McDevit and Saunders (2010) S. longicruris is now reduced to synonymy with $S$. latissima. In addition Agarum clathratum Dumortier may be found in deeper waters (Adey and Hayek 2011). On Greenland, Rosenvinge (1893) described a new kelp species as Laminaria groenlandica, meanwhile recognized as Saccharina groenlandica (Rosenvinge) C.E. Lane, C. Mayes, Druehl \& G.W. Saunders, but now eventually reduced to synonymy with S. latissima (Longtin and Saunders 2015).

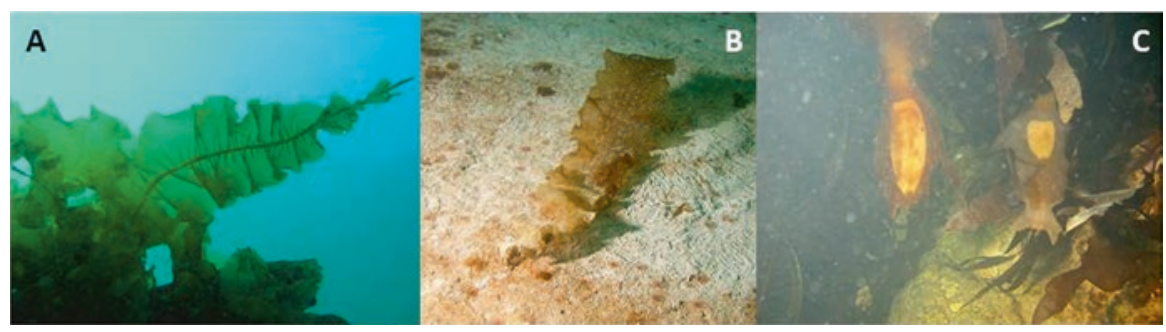

Fig. 10.1 Examples of kelps from Kongsfjorden: (a) Alaria esculenta is a kelp of Arctic to temperate distribution; due to its marked adaptive capacity it has been used in a multitude of ecophysiological studies on kelp responses to environmental changes. (b) Saccharina latissima on a small drop-stone drifting on soft bottom sediments; detached kelps are important vectors of organic matter transfer between hard and soft bottom habitats in Kongsfjorden. (c) Laminaria solidungula with characteristic hoof-shaped sori: As the only kelp endemic to the Arctic this species is believed to be particularly challenged by environmental change in Kongsfjorden. (All photos by Max Schwanitz, Alfred Wegener Institute) 
According to Pedersen (2011), all digitate Laminaria species on Greenland belong to Laminaria nigripes J. Agardh, a species originally described from Svalbard by Agardh in 1868 (Agardh 1868). According to Longtin and Saunders (2016), L. nigripes should be included in the genus Saccharina as Saccharina nigripes (J. Agardh) C. Longtin \& G.W. Saunders.

Kelp species in Svalbard are mostly the same as found along the Norwegian mainland. However, one additional species, Laminaria solidungula J. Agardh (Fig. 10.1c), occurs scattered around the entire island group (Hansen and Jenneborg 1996). Recent investigations from Isfjorden on Svalbard have reported the presence of Laminaria digitata, Saccharina latissima, Alaria esculenta, Saccorhiza dermatodea, and some small individuals of Laminaria solidungula (Fredriksen and Kile 2012). In Kongsfjorden, Hop et al. (2012) reported the same species to be present in an investigation from Hansneset in 1996/98. Fredriksen et al. (2014) revisited the same site as Hop et al. (2012) and found the same kelp species to be present in 2012/2013. The investigation by Hop et al. (2012) and Fredriksen et al. (2014) also pointed out the importance of kelp species for an overall rich benthic algal flora and fauna in Kongsfjorden. Recent investigations have shown the presence of Saccharina groenlandica at several sites in Svalbard, including Kongsfjorden (Lund 2014; Moy 2015; Fredriksen et al., Chap. 9). However, latest investigations suggest that this species should rather be regarded as a synonym to $S$. latissima (Longtin and Saunders 2015). The most important growth sites for kelps in Kongsfjorden are shown in Fig. 10.2.

Seaweed zonation patterns in Kongsfjorden have been studied intensively by diving down to $30 \mathrm{~m}$ depth at Hansneset, Blomstrand $\left(78^{\circ} 39^{\prime} \mathrm{N}, 1^{\circ} 57^{\prime} \mathrm{E}\right)$ from 1996 to 1998 (Hop et al. 2012) and from 2012 to 2014 (Fredriksen et al. 2014; Bartsch et al. 2016). Between time periods, considerable differences in the zonation pattern and especially in the floral biomass distribution along the shore became evident. In their investigation Fredriksen et al. (2014) surprisingly recorded the highest number of species in the littoral zone, a zone often considered to be a harsh environment due to the fluctuations in environmental factors. Compared to Hop et al. (2012), Fredriksen et al. (2014) found twice as many species growing in the littoral zone, 20 and 45 species, respectively.

The kelps Laminaria digitata and Alaria esculenta were found down to 15 and $18 \mathrm{~m}$ respectively, while Saccharina latissima was found between 1.5 and $16 \mathrm{~m}$ depth. Laminaria digitata and A. esculenta were dominant between 1.5 and $9.5 \mathrm{~m}$ while S. latissima reached its maximum dominance between 7.5 and $11.5 \mathrm{~m}$ as identified by a combination of biomass data and cover. The endemic Arctic kelp Laminaria solidungula was present there as an understorey species as well but never reached dominance. The kelp-like species Saccorhiza dermatodea grew between 1.5 and $13 \mathrm{~m}$ with maximum abundance between 1.5 and $5.5 \mathrm{~m}$. Laminaria digitata, A. esculenta and $S$. dermatodea reached highest biomasses at $5 \mathrm{~m}$ depth, whereas maximum biomass in $S$. latissima was recorded at $10 \mathrm{~m}$ (Table 10.1).

Below the kelp forest, a variety of brown and red algae were common to dominant. The brown algae Desmarestia aculeata (L.) J.V. Lamouroux and D. viridis (O.F. Müller) J.V. Lamouroux as well as the red alga Polysiphonia arctica J. Agardh occurred down to $20.5 \mathrm{~m}$ depth. The red algae Phycodrys rubens (L.) Batters and Ptilota gunneri 


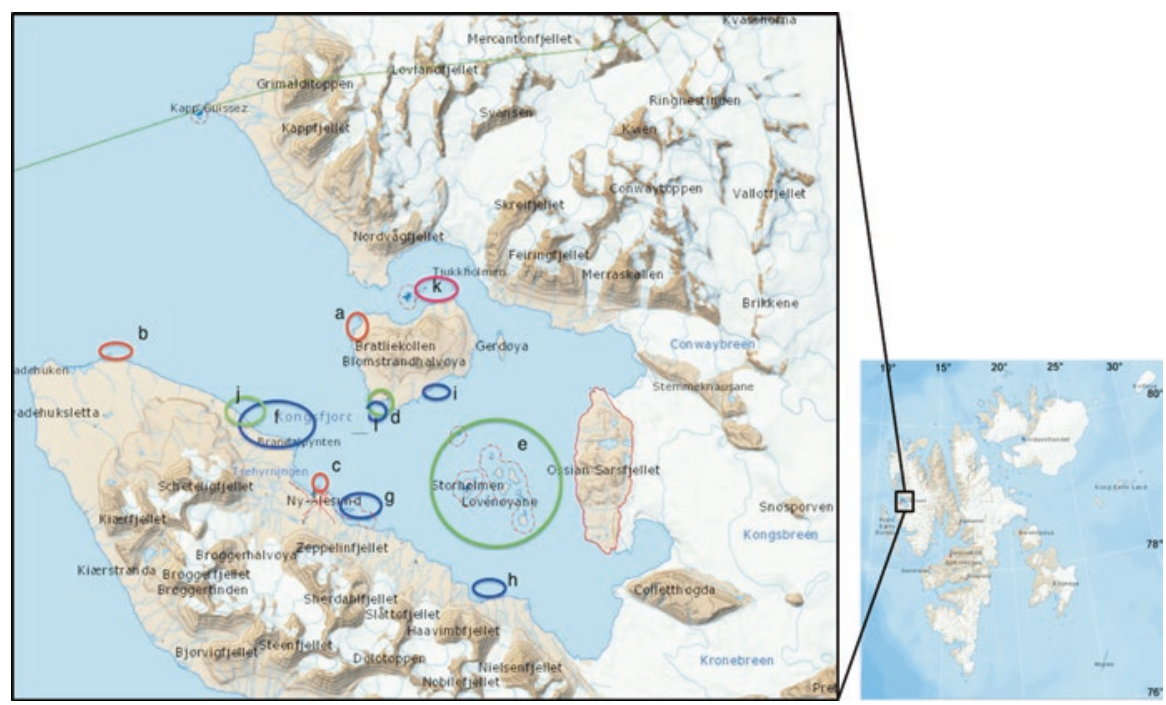

Fig. 10.2 Location of Kongsfjorden within the Svalbard Archipelago; main growth sites of kelps in Kongsfjorden as observed by scientific diving (maps compiled from toposvalbard.npolar.no):

\begin{tabular}{|c|c|c|}
\hline Location & Site characteristics & Dominant species \\
\hline $\mathbf{a}$ & Kelp forest on rocky substrate & $\begin{array}{l}\text { Alaria esculenta, Saccharina latissima, } \\
\text { Laminaria digitata, Laminaria solidungula }\end{array}$ \\
\hline b & Kelp forest on rocky substrate & A. esculenta \\
\hline c & $\begin{array}{l}\text { Kelp forest on rocky substratum } \\
\text { (mainly artificial structures) }\end{array}$ & A. esculenta, S. latissima \\
\hline d & $\begin{array}{l}\text { Minor kelp assemblages in the upper } \\
\text { subtidal zone }\end{array}$ & S. latissima, A. esculenta, L. digitata \\
\hline $\mathbf{e}$ & $\begin{array}{l}\text { Minor kelp assemblages in the upper } \\
\text { subtidal zone }\end{array}$ & S. latissima, A. esculenta, L. digitata \\
\hline f & $\begin{array}{l}\text { Seaweed on dropstones on sandy } \\
\text { bottom }\end{array}$ & A. esculenta, L. digitata \\
\hline $\mathbf{g}$ & $\begin{array}{l}\text { Seaweed on dropstones on sandy to } \\
\text { muddy bottom }\end{array}$ & $\begin{array}{l}\text { A. esculenta, L. digitata; below } 17 \mathrm{~m} \text { also } L \text {. } \\
\text { solidungula }\end{array}$ \\
\hline $\mathbf{h}$ & $\begin{array}{l}\text { Seaweed on dropstones on muddy } \\
\text { bottom }\end{array}$ & A. esculenta, L. digitata \\
\hline i & $\begin{array}{l}\text { Seaweed on dropstones on sandy sedi- } \\
\text { ment, coarse gravel and rocky } \\
\text { structures }\end{array}$ & A. esculenta, L. digitata \\
\hline $\mathbf{j}$ & $\begin{array}{l}\text { Small kelp assemblages in the upper } \\
\text { subtidal zone (narrow rocky band along } \\
\text { the coast) }\end{array}$ & S. latissima, A. esculenta, L. digitata \\
\hline $\mathbf{k}$ & $\begin{array}{l}\text { Kelp assemblages on dropstones or } \\
\text { rocky structures covered with muddy } \\
\text { sediment }\end{array}$ & S. latissima \\
\hline 1 & $\begin{array}{l}\text { Seaweed on dropstones on sandy to } \\
\text { muddy sediment or on large boulders }\end{array}$ & $\begin{array}{l}\text { Mainly A. esculenta and } S \text {. latissima, some } \\
L \text {. digitata on shallow rocks close to the } \\
\text { coastline }\end{array}$ \\
\hline
\end{tabular}


Table 10.1 Comparison of depth distribution of kelps at Hansneset (site "a" in Fig. 10.2), Kongsfjorden between 1996-1998 and 2012/2013 and occurrence of maximum biomass value (dark grey: high biomass, light grey: species recorded). The lower depth distribution limits (LDL) were recorded in 1996-1998 and in 2014

\begin{tabular}{|c|c|c|c|c|c|c|c|c|c|}
\hline \multicolumn{10}{|c|}{ Depth (m) } \\
\hline & 0.0 & 1.5 & 2.5 & 5.0 & 7.0 & 10 & 15 & $\mathrm{LDL}(\mathrm{m})$ & Year \\
\hline \multirow[t]{2}{*}{ Saccorhiza dermatodea } & & & & & & & & 13 & $1996-1998$ \\
\hline & & & & & & & & 12 & 2012-2014 \\
\hline \multirow{2}{*}{ Alaria esculenta } & & & & & & & & 15 & 1996-1998 \\
\hline & & & & & & & & 18 & 2012-2014 \\
\hline \multirow[t]{2}{*}{ Laminaria digitata } & & & & & & & & 15 & $1996-1998$ \\
\hline & & & & & & & & 10 & 2012-2014 \\
\hline \multirow[t]{2}{*}{ Laminaria solidungula } & & & & & & & & 5 & $1996-1998$ \\
\hline & & & & & & & & 10 & 2012-2014 \\
\hline \multirow[t]{2}{*}{ Saccharina latissima } & & & & & & & & 16 & 1996-1998 \\
\hline & & & & & & & & 14 & 2012-2014 \\
\hline
\end{tabular}

Compiled from Hop et al. (2012) and Bartsch et al. (2016)

P.C. Silva, Maggs et J.N. Heine grew at least down to $30 \mathrm{~m}$ depth. During a study using a remotely operated vehicle (ROV) in 2005, P. rubens was observed growing attached at $60 \mathrm{~m}$ depth (C. Wiencke, unpubl.). In contrast, the red alga Odonthalia dentata (L.) Lyngbye grew down to $15.5 \mathrm{~m}$ depth. Many of the species of this belt below the kelp forest occur also within the understorey of the kelp forest. Further subcanopy species with varying dominances as identified by a combination of biomass data and cover were the red algae Devaleraea ramentacea (L.) Guiry, Palmaria palmata (L.) Kuntze and Coccotylus truncatus (Pallas) M.J. Wynne et J.N. Heine.

When re-examining species composition at Hansneset in 2012/2014, several mostly small and inconspicuous species were recorded for the first time (Fredriksen et al. 2014). One species, Sphacelorbus nanus (Nageli ex Kützing) Draisma, Prud'homme \& H. Kawai, represents a new record for Svalbard, 14 species are new records for Kongsfjorden. A considerable increase from 20 to 45 species was recorded in the littoral zone between both sampling periods. Overall, the total macroalgal species diversity of Kongsfjorden increased to 78 (Fredriksen et al., Chap.9). While 62 species were found in 1996/98 and 58 in 2012/2013, only 42 were common to both investigations. Strikingly, some conspicuous red algae that had been recorded in 1996/98, such as Hildenbrandia rubra (Sommerfelt) Meneghini, Palmaria palmata (L.) Weber \& Mohr, Polysiphonia spp., or Scagelia pylaisaei (Montagne) M.J. Wynne were not found again. Based on these results, Fredriksen et al. (2014) came to the conclusion that indirect signs of global warming are apparent. Although the number of species in the two investigations was similar, there was a striking increase in species number in the littoral zone, possibly a result of reduced ice-scouring over the last years. In a follow-up-study performed in 2012-2014 at the same site, Bartsch et al. (2016) showed changes in biomass and depth distribution of most dominant brown algae. In particular, they demonstrated a 1.7 fold increase in overall seaweed biomass and a 4.7 fold increase of seaweed biomass at $2.5 \mathrm{~m}$ depth compared to 1996-98. The species with the highest biomasses were in this 
sequence: L. digitata, A. esculenta and S. latissima. It is important to note that biomass of these perennial species increased considerably in 2012-14, while the biomass of the annual Saccorhiza dermatodea decreased strongly compared to $1996 / 1998$. Moreover, the biomass maximum recorded in 1996/1998 at $5 \mathrm{~m}$ was shifted to more shallow waters in 2012-2014. Additionally, the lower depth limit of most dominant brown algae was elevated by approx. 2-3 $\mathrm{m}$. This complex pattern was regarded by Bartsch et al. (2016) as a consequence, firstly, of the reduction of fast ice since the winter 2005/2006 (Cottier et al. 2007) and, secondly, of the insufficient light conditions for kelp growth in greater depths because of an increased water turbidity as a result of increased sedimentation. One exception, however, was A. esculenta, which was found 3 m deeper in 2012-2014 compared to 1996/1998 (Table 10.1). This species presumably takes advantage of the relatively thin structure of the phylloid allowing a better potential for acclimation to low light conditions.

Overall, these findings support similar observations obtained between 1980 and 2010 at Kongsfjordneset $\left(78^{\circ} 58.60^{\prime} \mathrm{N}, 1^{\circ} 30.10^{\prime} \mathrm{E}\right)$ and Smeerenburgfjorden $\left(79^{\circ} 41.33^{\prime} \mathrm{N}, 11^{\circ} 04.00^{\prime} \mathrm{E}\right.$; Kortsch et al. 2012). In both Arctic fjords, abrupt and substantial changes in the structure of benthic communities were documented concurring with a gradual increase in annual average sea-surface temperature (SST) and increasing duration of the ice-free period. The structure of the two benthic communities remained relatively uniform between 1980 and 1992/1994 but changed rapidly thereafter. In Kongsfjorden, brown algal cover was sparse until 1995 but increased rapidly to $80 \%$ in 1996 . After this period, macroalgal cover fluctuated around 40\%. Similar findings were obtained in Hornsund, in the south of Svalbard, where a threefold increase in biomass was recorded between 1988 and 2008 (Weslawski et al. 2010). Kortsch et al. (2012) concluded that the changes at Kongsfjordneset and Smeerenburgfjord were related to changes in sea surface temperatures, increasing length of the ice-free season and concomitant enhanced light conditions together with changes in competition and grazing.

The described species composition and zonation pattern at Hansneset changes considerably along the fjord axis (Hop et al. 2016), and are certainly depending on the temperature, sedimentation and light regime and the degree of exposure in the different parts of the fjord.

\subsection{Environmental Settings for Kelps Populating Kongsfjorden}

\subsubsection{Light Availability \& Radiation Climate}

The overall atmospheric radiation conditions over Kongsfjorden are governed by pronounced seasonal differences resulting from the location's high latitude. The fundamentals of the light regime in Kongsfjorden have been characterized by Hanelt et al. (2001). 
The most obvious peculiarity of radiation conditions at such high latitude is the change in atmospheric radiation conditions during the polar day and night. At Kongsfjorden $\left(78^{\circ} 55^{\prime} \mathrm{N}, 11^{\circ} 56^{\prime} \mathrm{E}\right)$, the polar day lasts from 21 April to 22 August and the polar night from 26 October to 14 February. Even during the summer season with $24 \mathrm{~h}$ of daylight, maximum irradiances of photosynthetically active radiation (PAR) are comparatively low as a consequence of the low solar angle over the Arctic (Svendsen et al. 2002). Hence, maximal irradiance is considerably lower than the equator and in temperate regions and hardly exceeds $1200 \mu \mathrm{mol}$ photons PAR m ${ }^{-2} \mathrm{~s}^{-1}$ (Bischof et al. 1998a). Average annual PAR flux in Ny-Ålesund has been estimated at approximately $1000 \mathrm{MJ} \mathrm{m}^{-2}$, as determined by the local station of the Baseline Surface Radiation Network (BSRN; Hanelt et al. 2001). For comparison, at Helgoland, German Bight, North Sea at $54^{\circ} \mathrm{N}$ the annual PAR flux is approximately twice as high (Lüning 1990).

Obviously, apart from the seasonal changes, prevailing weather conditions largely govern the atmospheric radiation regime, while aerosols and other airborne particles currently play a minor role at this high latitude, apart from emissions of combusted fuel during the cruise ship peak season in summer (Eckhardt et al. 2013). Next to the photosynthetically active radiation range, the spectral component of ultraviolet radiation (UVR) has been shown to have considerable impact on kelp biology and this influence has been intensively studied at Kongsfjorden (Bischof et al. 2006). Maximum values of ultraviolet B (280-320 nm, UVB) radiation have been measured to be about $0.27 \mathrm{~W} \mathrm{~m}^{-2}$ (Hanelt et al. 2001), and in addition to season and weather conditions are furthermore influenced by stratospheric ozone concentration (Harris et al. 2008).

While we observe high variability in atmospheric radiation conditions, the underwater light climate is shaped by a multitude of further parameters, including water turbidity as influenced by any kind of particle load (phytoplankton cells, suspended sediments etc.), height of water column resultant from vertical depth distribution and additionally governed by tidal changes, and the presence/absence of sea ice cover. The optical characteristics of the water column can be characterised in a straightforward manner by determining the vertical attenuation coefficient $\mathrm{Kd}$, as described for Kongsfjorden by Hanelt et al. (2001). Irrespective of atmospheric and hydrographic conditions on the larger scale, the only meaningful radiation conditions to kelps are those shaping the in situ microenvironment. Hence, regardless of atmospheric light availability, only photons captured by the photosynthetic antennae or by light-sensing pigments matter to the respective individual of kelp. Also, the amount of quanta in the ultraviolet range of the spectrum, which may hit the actual kelp surface and eventually damage any kind of biomolecule is still difficult to assess from surface radiation measurements. The in situ (micro)light climate is modulated by the orientation to solar exposure, the slope of the substrate, the presence or absence of a canopy (either from the same or different species), to name just a few of the influencing factors. Moreover, identical radiation conditions may exert differential effects on kelp cells, depending of the different tissues, age, life-history stage etc. (see Sect. 10.4.5). 
With respect to environmental changes to be expected in the Kongsfjorden ecosystem, one of the most burning questions concerns the future radiation climate in Kongsfjorden. It needs to be carefully evaluated whether light availability to benthic kelp communities will be increasing or decreasing as the outcome of environmental change in Kongsfjorden. Obviously, sea ice cover persisting into spring and, thus, shielding benthic communities from radiation during a period usually characterized by very transparent water conditions (Hanelt et al. 2001) will become an extremely rare event. Conclusively, more light will become available in early spring, which may facilitate an earlier onset of the productive season. It may thus be argued that the flourishing season for kelps might become extended by an earlier and higher light availability in the absence of sea ice. On the other hand, the extremely clear waters right at that time, connected to the higher UVB irradiance reaching the earth surface in early spring season may confer inhibitory processes to kelp photosynthesis and production (Bischof et al. 2006), counterbalancing the promoting effect described above. Moreover, new records of stratospheric ozone loss over the Arctic have been registered recently (Manney et al. 2011), as a direct outcome of the interaction with climate warming. Increase in $\mathrm{CO}_{2}$ will lead to temperature increases in the troposphere and will prevent the efflux of heat energy to the stratosphere. Thus, a considerable cooling of the stratosphere is expected, which will promote the formation of polar stratospheric clouds and ultimately facilitating ozone breakdown (Harris et al. 2008). Consequently, for atmospheric radiation conditions, a higher UVB burden in the Arctic is likely. It is, however, questionable to what extent the higher UVB load will propagate into subtidal communities: The higher UVB load might be most critical in early spring, but might also be diminished if not completely prevented by increased water turbidity later in season. This is because of another likely scenario Kongsfjorden might face: higher atmospheric temperatures will promote glacier melting and, in combination with a likely increase in precipitation, result in increasing terrestrial run-off and particle discharge into the fjord system, which will result in increased attenuation, with higher absorbance in the shorter wavelength range (Hanelt et al. 2001, Sect. 10.3.2). The modulation of the underwater light climate by an increased sediment load is documented by attenuation measurements along the fjord axis. High loads of glacier-derived sediment reduce light availability in the inner part of the fjord, while overall the effect of sediment diminishes westward along the fjord axis (Svendsen et al. 2002, Wlodarska-Kowalczuk et al. 2005).

\subsubsection{Terrestrial Run-Off: Sedimentation \& Salinity Change}

In Kongsfjorden, sediment accumulation rates range from $200-20,000 \mathrm{~g} \mathrm{~m}^{-2} \mathrm{yr}^{-1}$ from the outer to inner fjord, respectively (Svendsen et al. 2002). The sediments being released to the fjord may affect kelp communities in two ways: On a larger scale (and as outlined above), sedimentation will result in a reduction of PAR, which may result in a reduction of maximum photosynthetic rates and ultimately affect 
system productivity. At the same time, kelps might be shielded from harmful UV radiation (Roleda et al. 2008). However, whether this represents an effect of ecological significance remains to be resolved. On a smaller scale, sinking sediments may eventually settle on kelp blades, where they may become adhesive, being glued by the polysaccharide mucilage covering the phylloid surface (Roleda et al. 2008). This may interfere with (i) light availability, but also with (ii) nutrient exchange and (iii) hydrodynamics of kelp blades, as sediment-laden phylloids will be considerable heavier. In this way, massive discharge events may ultimately result in a smothering of entire benthic communities, turning an originally rocky habitat into a regime dominated by sediments with little substratum suitable for kelp settlement.

Another environmental variable in coastal waters altered by increased particle discharge from land and consequently potentially affecting kelp physiology is salinity. A gradient of decreasing salinity from the fjord mouth to the inner part of the fjord is established each summer, as a result of riverine freshwater run-off and glacier melting (Svendsen et al. 2002, Wlodarska-Kowalczuk et al. 2005). During summer, salinity drops from 34 to 28 in surface waters are frequently observed under the influence of glacial melting. Such low salinities may be reduced even further in riverine discharge plumes. Reduced salinity has been described as a stress factor to kelp zoospores and in particular in combination with other physicochemical stressors. Fredersdorf et al. (2009) showed that photosynthetic quantum yield of spores of Alaria esculenta has been inhibited by salinities of approximately 20 and that spore germination is markedly impaired by the interaction of reduced salinity, elevated temperature and UV-exposure. As we will see below, the particular susceptibility of kelp spores towards environmental perturbation is of utmost significance to kelp population biology.

\subsubsection{Temperature Increase and Ocean Acidification}

The rising anthropogenic $\mathrm{CO}_{2}$ emissions trigger the atmospheric greenhouse effect and also influence ocean warming. Subsequent $\mathrm{CO}_{2}$ dissolution that buffers climate change in the terrestrial system further makes the world's ocean less basic (i.e. lower $\mathrm{pH}$ ). The decadal $0.15^{\circ} \mathrm{C}$ increase in global surface temperature (IPCC 2013) is most likely responsible for the $0.7{ }^{\circ} \mathrm{C}$ increase in global average sea surface temperature (SST) during the last century (Hulme et al. 2002). The recently projected increase in average surface temperature by $1.0-4.0{ }^{\circ} \mathrm{C}$ in the year 2100 (IPCC 2013) may further increase the average global SST.

On Spitsbergen, continuous monitoring of atmospheric $\mathrm{CO}_{2}$ was commenced in October 1988 and has continued ever since (Engardt et al. 1996). From the atmospheric $\mathrm{CO}_{2}$ record, the oceanic $\mathrm{CO}_{2}$ uptake and terrestrial net $\mathrm{CO}_{2}$ uptake was estimated using a high resolution regional atmospheric transport model and supported by complimentary $\delta^{13} \mathrm{C}$ data (Engardt and Holmén 1996). Moreover, long-term time-series of air temperature measurements in Spitsbergen (1898-2012) showed a significant temperature increase from the 1960s. The trend showed an annual mean 
increase of $2.6^{\circ} \mathrm{C}$ century ${ }^{-1}$ and a high seasonal increase during spring at $3.9^{\circ} \mathrm{C}$ century ${ }^{-1}$. Svalbard has experienced the greatest temperature increase during the last three decades compared to other regions in Europe (Nordli et al. 2014).

Approximately one third of the global anthropogenic $\mathrm{CO}_{2}$ emissions is absorbed by the world's oceans. The reaction of $\mathrm{CO}_{2}$ with $\mathrm{H}_{2} \mathrm{O}$ perturbs the seawater carbonate system and the increase in hydrogen ion concentration lowers $\mathrm{pH}$ because $\mathrm{pH}=-\log _{10}\left[\mathrm{H}^{+}\right]$, a process known as ocean acidification (OA). For example, in present surface seawater with $\mathrm{pH}$ of $\sim 8.07$, approximately $91 \%$ of the inorganic carbon $(\mathrm{Ci})$ is $\mathrm{HCO}_{3}^{-}, 8 \% \mathrm{CO}_{3}{ }^{2}$, and only $1 \% \mathrm{CO}_{2 \text { (aq) }}$. Under a more acidified ocean scenario in the year 2100, concentrations of $\mathrm{CO}_{2}(\mathrm{aq})$ and $\mathrm{HCO}_{3}{ }^{-}$are predicted to increase by $200 \%$ and $9 \%$, respectively, and $\mathrm{CO}_{3}{ }^{2}$ - decrease by $56 \%$, with a concomitant decline in $\mathrm{pH}$ to 7.65 (Royal Society 2005). The Polar Seas and the cold temperate regions, e.g. the northern Atlantic, are projected to be more vulnerable to OA because cold water absorbs more $\mathrm{CO}_{2}$ (McNeil and Matear 2008; Roleda and Hurd 2012).

$\mathrm{CO}_{2}$ is the substrate for photosynthesis, but only $1 \%$ of $\mathrm{Ci}$ present in today's oceans exists as $\mathrm{CO}_{2}$, while $91 \%$ exists as $\mathrm{HCO}_{3}{ }^{-}$. Therefore, it is not surprising that most seaweeds are able to utilize $\mathrm{HCO}_{3}{ }^{-}$from the bulk seawater to compensate for the low availability of $\mathrm{CO}_{2 \text { (aq) }}$. The diverse mechanisms involved in the use of $\mathrm{HCO}_{3}{ }^{-}$ are termed $\mathrm{CO}_{2}$ concentrating mechanisms (CCMs) which in most cases comprise at least three functional elements: (1) influx of $\mathrm{CO}_{2}$ and/or $\mathrm{HCO}_{3}{ }^{-}$, (2) uptake of $\mathrm{Ci}$ inside the cell (usually as $\mathrm{HCO}_{3}^{-}$) and (3) production of $\mathrm{CO}_{2}$ from the $\mathrm{Ci}$ pool around the $\mathrm{CO}_{2}$-fixing enzyme Ribulose 1,5, bisphosphate Carboxylase/Oxygenase (RuBisCO). The role of different isozymes of carbonic anhydrase (CA) in the reversible enzymatic conversion of $\mathrm{HCO}_{3}{ }^{-}$to $\mathrm{CO}_{2}$ in different cellular compartments suggests that photosynthesis is saturated under the current seawater Ci concentration (cf Fernández et al. 2015). Studies on the carbon physiology of various Atlantic kelp species, e.g. Laminaria digitata, Laminaria hyperborea, Saccharina latissima, Alaria esculenta and Phyllariopsis purpurascens (Surif and Raven 1989; FloresMoya and Fernández 1998; Axelsson et al. 2000; Klenell et al. 2004; Mercado et al. 2006), suggest diverse species-specific inorganic carbon uptake mechanisms (details reviewed in Fernández et al. 2014).

The effects of $\mathrm{OA}$ in isolation and in interaction with other stressors on kelp physiology have been studied extensively on the Pacific giant kelp Macrocystis pyrifera (L.) Agardh (e.g. Roleda et al. 2012a; Brown et al. 2014; Fernández et al. 2014, 2015; Gaitan-Espitia et al. 2014;), i.e. more than in any other Atlantic kelp species (e.g. Olischläger et al. 2012; Gordillo et al. 2015). Only Gordillo and co-workers (2015) investigated OA and UVR on the Arctic population of Saccharina latissima and Alaria esculenta from Kongsfjorden. It has been suggested that fleshy seaweeds, such as kelps, will likely benefit under high $\mathrm{CO}_{2}$ concentrations as they will increase their $\mathrm{CO}_{2}$ use and down-regulate 'energetically-expensive' active $\mathrm{HCO}_{3}^{-}$ -use mechanisms, thereby saving energy to allocate more resources into growth. This hypothesis, however, requires further physiological experiments such as those by Fernández and co-workers $(2014,2015)$, who showed that $\mathrm{HCO}_{3}^{-}$remains the main source of inorganic carbon $(\mathrm{Ci})$ assimilated by the geographically widely 
distributed, i.e. from warm-temperate to sub-polar regions, giant kelp Macrocystis pyrifera to support photosynthesis under both high $(=\mathrm{pH} 7.65)$ and low $(=\mathrm{pH} 9.00)$ $p \mathrm{CO}_{2}$. Consequently, photosynthetic $\left(\mathrm{O}_{2}\right.$ evolution) and growth rates of $M$. pyrifera were not significantly enhanced under ocean acidification (Fernández et al. 2015). On the contrary, under high $\mathrm{CO}_{2}$ and UVR exposure, higher growth rates in Saccharina latissima and Alaria esculenta from Kongsfjorden were reported (Gordillo et al. 2015). The use of pulse-amplitude modulated (PAM) chlorophyll fluorescence for photopysiological measurements of e.g. the maximum quantum yield of PSII $(\mathrm{Fv} / \mathrm{Fm})$ as a proxy to measure effects of ocean acidification should be interpreted with care as the mechanism of how quantum yield may be affected by the bulkwater $\mathrm{pH}$ still needs to be elucidated (Rautenberger et al. 2015).

A fundamental understanding of organismal physiology, especially for the structural canopy-forming kelps, is very important as scientists assess how foundation species and ecosystem engineers might respond to the changes in seawater carbonate chemistry predicted under OA. However, it should be noted that despite the $200 \%$ increase in $\mathrm{CO}_{2}, \mathrm{HCO}_{3}{ }^{-}$concentration remains $97 \%$ higher compared to $\mathrm{CO}_{2}$ (Raven et al. 2005). Whether the overall effect of OA is negative, positive or neutral will depend on its direct and indirect effects: is the effect due to increase in $\mathrm{CO}_{2}$ alone or due to the increase in total dissolved inorganic carbon (DIC: $\mathrm{CO}_{2}+\mathrm{HCO}_{3}^{-}$) and/or due to the concomitant decrease in $\mathrm{pH}$ and increase in $\mathrm{H}^{+}$? For example, a 0.1 unit decrease in $\mathrm{pH}$ corresponds to a $30 \%$ increase in $\mathrm{H}^{+}$; how this substantial increase in $\mathrm{H}^{+}$affects organismal metabolism requires in-depth studies (cf Roleda et al. 2012b). Among the several functions of $\mathrm{H}^{+}$, it modulates membrane channel functioning, intracellular signalling and ion availability (Busa 1986; Taylor et al. 2012). Therefore, OA studies should be conducted under rigorously controlled experimental conditions in which only specific carbonate chemistry parameters are manipulated and all other conditions (e.g. light, temperature, water flow, nutrients) are kept at optimum levels.

The effects of OA have been studied on early life history stages of different coldtemperate kelp species, e.g. Macrocystis pyrifera and Laminaria hyperborea. In M. pyrifera, meiospore germination was reduced by $9 \%$ only under extreme OA $\left(p \mathrm{CO}_{2}=1200 \mathrm{ppm} ; \mathrm{pH}=7.59-7.61\right)$. Moderate $\mathrm{OA}\left(p \mathrm{CO}_{2}=830 \mathrm{ppm} ; \mathrm{pH}=7.76\right)$ had no effect on meiospore germination rate, and cells even grew bigger compared to those grown under pre-industrial $\mathrm{CO}_{2}$ levels $\left(\mathrm{CCO}_{2}=270 \mathrm{ppm} ; \mathrm{pH}=8.19\right)$ (Roleda et al. 2012a). In concurrence, Gaitan-Espitia et al. (2014) showed that meiospore mortality was enhanced only under interactive effects of extreme OA $\left(p \mathrm{CO}_{2}=1800 \mathrm{ppm}\right)$ and increase in temperature $\left(+5^{\circ} \mathrm{C}\right.$ of the ambient $)$; at ambient temperature and high $\mathrm{CO}_{2}$, meiospores were observed to undergo dormancy (GaitanEspitia et al. 2014). On the other hand, a study on various life history stages of another cold-temperate kelp species, Laminaria hyperborea, showed that female gametogenesis and sporophyte growth can be significantly enhanced under high $\mathrm{CO}_{2}$ (Olischläger et al. 2012).

Aside from the effect of OA on species physiology, growth, reproduction, and survival, it is also important to consider the effect of OA on species competition, top-down control by herbivores, and ecosystem diversity and resilience (Harley 
et al. 2012; Connell et al. 2013; Falkenberg et al. 2014). Whether kelps and other fleshy seaweed will benefit from OA and competitively exclude OA-sensitive species such as coralline algae requires detailed investigation with robust experimental design (Roleda et al. 2015). A diverse benthic algal assemblage may be able to buffer the negative effects of $\mathrm{OA}$ on $\mathrm{pH}$-sensitive species, e.g. calcifying organisms (Jury et al. 2013, Jokiel et al. 2014, Roleda et al. 2015). For example, high $\mathrm{CO}_{2}$ /low $\mathrm{pH}$ has a neutral rather than negative effect on net primary productivity of coralline-kelp assemblages (Tait 2014). Overall, research on the impacts of OA on fleshy seaweeds and benthic algal communities from Polar Regions is limited; however, kelp species from cold-temperate regions appear to be resilient to OA. To clarify whether the seaweed community of Kongsfjorden (as described in Sect. 10.2) will experience long-term changes under the impact of OA will require intense research efforts including benthic in situ manipulation experiments.

The upper survival temperatures (USTs) of 16 non-canopy forming seaweed species from Greenland were observed to be much higher than the ambient temperatures (Bischoff and Wiencke 1993). A group of stenothermic species grows within $0-20{ }^{\circ} \mathrm{C}$ range, with a growth optima between 0 and $10{ }^{\circ} \mathrm{C}$ and a UST of $17-23{ }^{\circ} \mathrm{C}$. Another group of eurythermic species grows in the same temperature range but with optimum growth at 10 or $15^{\circ} \mathrm{C}$ and a UST of $24-31^{\circ} \mathrm{C}$ (Bischoff and Wiencke 1993). Among the large canopy-forming kelp species, the large-scale disappearance of Saccharina latissima in 2002 in southern Norway was partly attributed to increasing summer water temperatures; and recovery of the species has been limited at low abundances (Moy and Christie 2012). Seawater temperature does not only control survivorship but also growth and reproduction. For example, temperatures higher than $15.5{ }^{\circ} \mathrm{C}$ reduced the productivity of farmed Saccharina japonica (Areschoug) C.E. Lane, C. Mayes, Druehl \& G.W. Saunders by $10 \%$ compared to cooler years (Suzuki et al. 2008); while high summer seawater temperature $\left(18{ }^{\circ} \mathrm{C}\right)$ inhibited sporogenesis in another species, Laminaria digitata, where sorus formation is optimal between $5-10^{\circ} \mathrm{C}$ (Bartsch et al. 2013). Moreover, seawater temperatures above $17.5^{\circ} \mathrm{C}$ induce a higher tissue erosion rate, exceeding that of growth rate (Suzuki et al. 2008). The projected increase in surface ocean temperature is predicted to have major impacts on coastal ecosystems, including the decimation of kelp forests at their southern range limit, and their poleward range extension (Müller et al. 2009a; Raybaud et al. 2013; Brodie et al. 2014). However, early life history stages of Arctic endemic kelp and Arctic ecotypes of North Atlantic Laminariales can survive temperatures higher than ambient (Roleda 2009, 2016). Whether species have distinct strategies to respond to climate change by adaptation or migration, or will succumb to local extinction remains to be investigated.

\subsubsection{Nutrient Regime}

There is only scant information about the nutrient regime governing pelagic and benthic primary productivity in Kongsfjorden, but this has been the focus of some of the most recent on-site research activities. Nitrogen compounds have long been 
recognised to limit macroalgal productivity. In the Arctic, the maintenance of metabolism at near-freezing temperatures requires a high concentration of enzymatic proteins (Machalek et al. 1996), which constitute a major nitrogen-containing cell component. Thus, polar algae in general are expected to have a considerable demand for nutrients. However, unlike in Antarctica, Arctic waters show strong seasonality in nutrient availability. The general pattern of nutrient availability in Kongsfjorden is as follows: a relatively high concentration of nitrate, phosphate and silicate during winter allowing phytoplankton blooms to develop in spring once the sun has returned and waters are free of ice (Rokkan Iversen and Seuthe 2011; Hegseth and Tverberg 2013; Piquet et al. 2015). Annual variations of nitrate for the year 2006 are shown in Fig. 10.3. During the phytoplankton bloom, nutrients are assimilated by microalgae and seawater gradually becomes nutrient depleted from late spring to autumn. This means that the period of maximum light availability is concomitant with a scarcity of nutrients and vice-versa. Although it is generally assumed that inorganic nitrogen is the main limiting factor for primary production in coastal systems, some tropical waters have been reported to be P-limited (e.g. Lapointe 2004). Following low N:P ratios during summer, this seems not to be the case in Kongsfjorden (Fig. 10.3).

Nutrient uptake and assimilation characteristics of macroalgae from temperate waters have been shown to vary among populations and species under local nutrient regimes (e.g. Hernández et al. 1993; Gordillo et al. 2001a). Arctic species are also

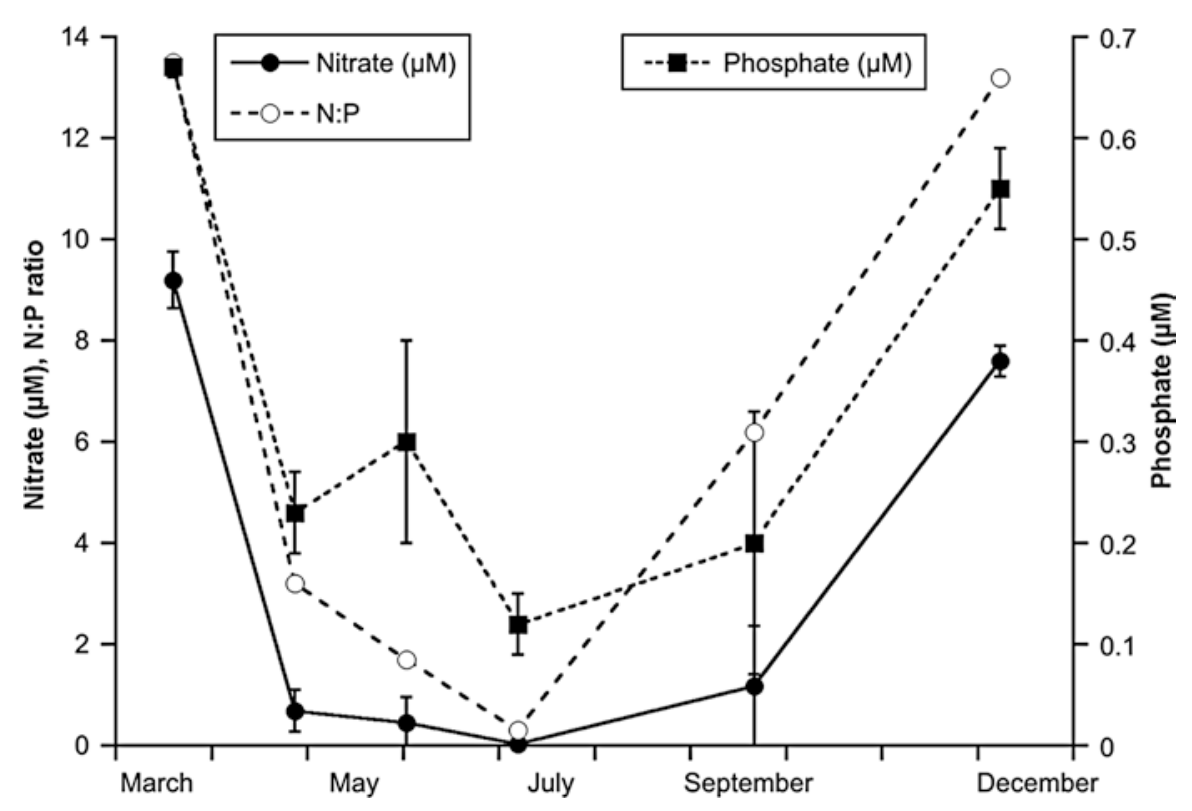

Fig. 10.3 Nitrate (+ nitrite) as well as phosphate concentrations, and N:P ratios in the upper $50 \mathrm{~m}$ of the water column near the village of Ny-Ålesund in 2006. Bars for $\pm \mathrm{SD}(\mathrm{n}=6)$. (Re-drawn from Rokkan Iversen and Seuthe 2011) 
reported to show nutritional traits that allow them to cope with the long periods of darkness in winter and nutrient depletion in summer (Korb and Gerard 2000a, b). Kelps living in the Arctic rely on stored photosynthates accumulated during the icefree $\mathrm{N}$-depleted summer period, supporting new growth during winter, during which, however, nutrient supply is sufficient. According to Korb and Gerard (2000a), the endemic Laminaria solidungula can be considered a "storage specialist" for nitrogen assimilation. Its high maximum nitrate uptake rate (Vmax), along with low growth rates, allows it to take advantage of seasonally elevated nutrient concentrations and to accumulate large internal pools of nitrate and organic $\mathrm{N}$-reserves. Traditionally, it was thought that this seasonal growth pattern was a direct consequence of $\mathrm{N}$ availability (Chapman and Lindley 1980) as well as light availability (Henley and Dunton 1997). However, it has been proposed that, at least in some species, this pattern might be under the control of an endogenous free-running circannual rhythm entrained by a critical minimum daylength in autumn (Lüning 1991, Schaffelke and Lüning 1994). This genetic clock would imply that the addition of nitrate to N-limited kelps during summer would have only a marginal effect on growth and biochemical composition, presumably due to the prevailing internal clock (Henley and Dunton 1997). Gordillo et al. (2006) confirmed that the effects of nutrient enrichment in midsummer on kelp biomass composition play only a marginal role in a number of species from Kongsfjorden. When thalli of 21 seaweed species collected in July were incubated for two days in nitrate- and phosphate-enriched seawater, the $\mathrm{C}: \mathrm{N}$ ratio was only affected by $7 \%$ on average, and it did not decrease significantly in any of the three kelps included in the study (Alaria esculenta, Saccharina latissima, and Laminaria solidungula). This lack of $\mathrm{N}$-accumulation would be in agreement with the internal clock prevailing over external nutrient conditions, which in summer would promote active photosynthesis over nutrient uptake.

However, $\mathrm{N}$-availability is not to be considered alone, as other factors might influence N use. Henley and Dunton (1997) reported changes in the biochemical composition of L. solidungula as an effect of light availability and the interaction of light and $\mathrm{N}$ rather than the addition of $\mathrm{N}$ alone. More recently, Iñiguez et al. (2016) found that increased levels of $\mathrm{CO}_{2}$ promoted $\mathrm{N}$ assimilation in Alaria esculenta collected in July, and incubated under N sufficiency. Similar stimulation of N assimilation by increased $\mathrm{CO}_{2}$ has been observed in the temperate Ulva rigida (Gordillo et al. 2001b). From the report by Gordillo et al. (2006) it could be concluded that $\mathrm{N}$ storage via $\mathrm{NO}_{3}{ }^{-}$internalisation during winter to early spring might be sufficient to overcome at least part of the summer with sufficient nitrogen availability. Kelps showed an accumulation factor (internal relative to external concentration) of up to 7000 (Table 10.2). However, in a later campaign in July 2009, the same authors failed to detect internal levels of inorganic $\mathrm{N}$ (unpublished), evidencing an interannual variation in $\mathrm{N}$ storage. Strong interannual changes in macroalgal cover have been reported for Kongsfjorden (Hop et al. 2012; Kortsch et al. 2012; Fredriksen et al. 2014; Bartsch et al. 2016), and further details are described in Sect. 10.2 of this review; but it is unknown to what extent nutrients contributed to this variability. It can be hypothesised that maximum biomass yield 
Table 10.2 Total C:N ratio, internal nitrate+nitrite concentrations $(\mathrm{mM})$ and concentration factor (internal:external) of three kelp species (Alaria esculenta, Laminaria solidungula, Saccharina latissima) from Kongsfjorden sampled in July 2002. Standard deviations in brackets $(\mathrm{n}=5)$

\begin{tabular}{l|l|l|l}
\hline & C:N & Internal nitrate + nitrite & Concentration factor \\
\hline Alaria esculenta & $23(0.6)$ & $1.9(0.4)$ & 4750 \\
\hline Laminaria solidungula & $20.5(0.9)$ & $2.7(1.3)$ & 6750 \\
\hline Saccharina latissima & $24.5(0.1)$ & $2.8(1.4)$ & 7000 \\
\hline
\end{tabular}

Taken from Gordillo et al. (2006)

and later survival during the long nutrient-limited season could be influenced by the timing of the phytoplankton bloom; but this pelago-benthic connection remains to be investigated.

Only for a few weeks in early spring, seaweeds encounter optimal conditions, i.e. an increasing availability of light, an increase in water temperature and ample nutrient availability before phytoplankton blooms initiate depletion. This period coincides with the maximum growth rate for some seaweeds, especially the season responders such as Saccharina latissima, which grow when irradiance and temperature are optimal for the species (Wiencke et al. 2009), and, in contrast, the so-called season anticipators grow under short-day or even dark conditions in winter and spring. An extreme example is Laminaria solidungula, where phylloid expansion begins in early winter and continues through the spring (Chapman and Lindley 1980). Nitrate availability is claimed to regulate growth (Chapman and Craigie 1977 ) in both cases. However, the timing of the phytoplankton bloom and the connected nutrient depletion can be quite variable. The presence/absence of sea ice and the depth of vertical mixing are important factors for the onset of the spring phytoplankton bloom (Hodal et al. 2011; Hegseth and Tverberg 2013). According to Hegseth and Tverberg (2013), the influx of Atlantic water to Kongsfjorden directly determines these two factors, and blooms can be anticipated as early as April or may be delayed to the end of May.

On the other hand, a warmer Arctic implies an increased volume of meltwater from glaciers. This increased influence of meltwater is expected to reduce the spring phytoplankton bloom, leading to low biomass and small cell-size communities (Piquet et al. 2014), which may in turn have consequences in nutrient availability for seaweeds during spring and summer. The nutrient distribution between phytoplankton and seaweeds might determine further changes in the main routes of the Kongsfjorden food web as depicted by Hop et al. (2002) and quantified by Duarte et al. (Chap. 12).

In addition to a possible nutrient-derived inter-annual variability, it has to be taken into account that globally increasing temperatures will be a main driver in seaweed distribution also in Svalbard (Kortsch et al. 2012, Jueterbock et al. 2013) as already reported for kelp beds in West Greenland (Krause-Jensen et al. 2012) and Norwegian mainland fjords (Husa et al. 2014), but the interaction of temperature and nutritional regimes have been rarely investigated in polar seaweeds (Korb and Gerard 2000b). 


\subsection{From Stress Perception to Community Responses}

\subsubsection{Stress Sensing \& Signal Transduction}

Evidently, under field conditions a multitude of factors is shaping the physicochemical environment of any species, and various abiotic drivers may or may not interact in a synergistic or antagonistic way. Thus, ecophysiological research on the consequences of environmental change needs to foster research on interactive effects, although these are complicated to assess. In order to reveal the molecular physiological bases of adaptive responses it is of particular interest to (1) discriminate between stress-specific vs. general stress responses and (2) characterise how environmental signals are perceived by kelps and transduced in order to trigger the respective physiological responses.

Algal growth, development, and reproduction are drastically affected by changes in temperature, humidity, salinity, irradiance (both PAR and UVR) and nutrient availability (Dring 1982; Davison and Pearson 1996; Gévaert et al. 2003; Gao and Xu 2010; Karleskint et al. 2010; Hurd et al. 2014). The expected increase in UVR as well as in atmospheric $\mathrm{CO}_{2}$ (with concomitant ocean acidification) may increase (or repress) the effect of those stressors, and the response and strategies of adaptation and acclimation to the stressors must be studied. In order to survive, macroalgae must adequately respond to changes in the environment. In general, survival in constantly changing environments requires metabolic networks capable of detecting stress signals and transducing them to the nucleus of the cell. These stress response mechanisms must be rapid as well as strongly regulated.

Susceptibility or tolerance to abiotic stresses is coordinated by various genes (Sect. 10.4.2), which are switched on and off and may cross-talk with other components of stress signal transduction pathways. Overall, in the case of seaweeds, stress tolerance is a complex phenomenon because as sessile organisms, seaweeds may go through multiple stresses at the same time. Mitogen-activated protein kinases (MAPK) are a group of cytoplasmic phosphoproteins that constitute the central core of the signalling network to respond to stress in most organisms. These kinases are highly conserved serine/threonine kinases found in all eukaryotic cells in combination with their upstream activators (MAPK kinases and MAPKK kinases), forming a "signalling cascade". The kinases are phosphorylated and activated in a sequential way to the associated downstream protein kinase. In animals, the p38 and stressactivated protein kinase/c-Jun N-terminal kinase (SAPK/JNK) cascades are responsible for stress adaptation, whereas the extracellular signal-regulated kinase (ERK) cascade is involved in mitogenic stimuli and differentiation (Widmann et al. 1999).

Despite the fact that the study of signal transduction in algae is very recent, different studies with both macro- and microalgae (Jiménez et al. 2004, 2007; GarcíaGómez et al. 2012; Parages et al. 2012, 2013, 2014a, b) have clearly shown the presence of p38-, JNK- and ERK-like components in algae, as well as their crucial role in acclimation to stress and in cell division (Parages et al. 2014a, b), revealing that phosphorylation of p38- and JNK-like MAPKs occurs in Arctic kelps in 
response to increasing UVR exposure and temperature (Parages et al. 2013) as well as in intertidal seaweeds at the onset of emersion and during periods of the highest irradiation (Parages et al. 2014a, b).

In a recent study, Parages et al. (2013) demonstrated a differential behaviour of MAPK response to changes in the environment (temperature and UVR) in two Arctic kelps from Kongsfjorden. The endemic Laminaria solidungula presented phosphorylated JNK- and p38-like proteins at steady-state conditions (PAR at $2{ }^{\circ} \mathrm{C}$ ), increasing after exposure to UVR and increased temperature (from 2 to $7^{\circ} \mathrm{C}$ ). In contrast, Saccharina latissima, a non-endemic species, showed a decrease in both JNK and p38 phosphorylation after temperature increase at any radiation condition, while UVR, as expected, also induced an increase in phosphorylation. In this species, p38 was more activated than JNK. The reason for this different response may be found in the fact that for L. solidungula an increased temperature to $7^{\circ} \mathrm{C}$ was close to its upper tolerance limit due to its endemic character, while in the case of S. latissima, $2{ }^{\circ} \mathrm{C}$ was close to its lower tolerance limit (Fig. 10.4). The differential behaviour of p38 and JNK phosphorylation in response to environmental stress also occurs in intertidal macroalgae (Parages et al. 2014a) and in microalgae (Jiménez et al. 2004, García-Gómez et al. 2012). These authors have concluded after analysis of six species of intertidal Chlorophytes, Phaeophytes and Rhodophytes and two species of the microalga Dunaliella that phosphorylation of p38-like MAPK always preceded that of JNK-like MAPK during acclimation to stress.

Evidence of the physiological role of p38-like and JNK-like pathways in algae is provided by the use of highly specific inhibitors of the signalling pathways. Jiménez et al. (2004) and Parages (2012) have shown that inhibition of p38 or JNK phosphorylation in both micro- and macroalgae highly impaired acclimation under stressing conditions, eventually leading to cell death.

\subsubsection{Gene Expression \& Transcriptomics}

In a second step, cells perceiving environmental signals respond with an up- or down-regulation of the expression of the appropriate genes, and regulation of gene expression plays a critical role in cellular differentiation, growth, development, as well as acclimation and adaptation to a variable environment in any organism (Rayko et al. 2010; Hurd et al. 2014).

Transcriptome profiling provides insights into an organism's response to changes in abiotic and biotic conditions, which helps to understand the physiological state of an organism across its range (Hofmann and Place 2007; Jamers et al. 2009). The availability of the first brown algal genome sequence (Cock et al. 2010) as well as the improvement and decreasing costs of high throughput sequencing gave rise to several de novo transcriptome-sequencing studies in kelps. Hence, transcriptomes of Saccharina japonica, Saccharina latissima, and Macrocystis pyrifera are now available among others (Heinrich et al. 2012a; Konotchick et al. 2013; Sun et al. 2014; Wu et al. 2014). Nevertheless, studies on comparative genome-wide gene 


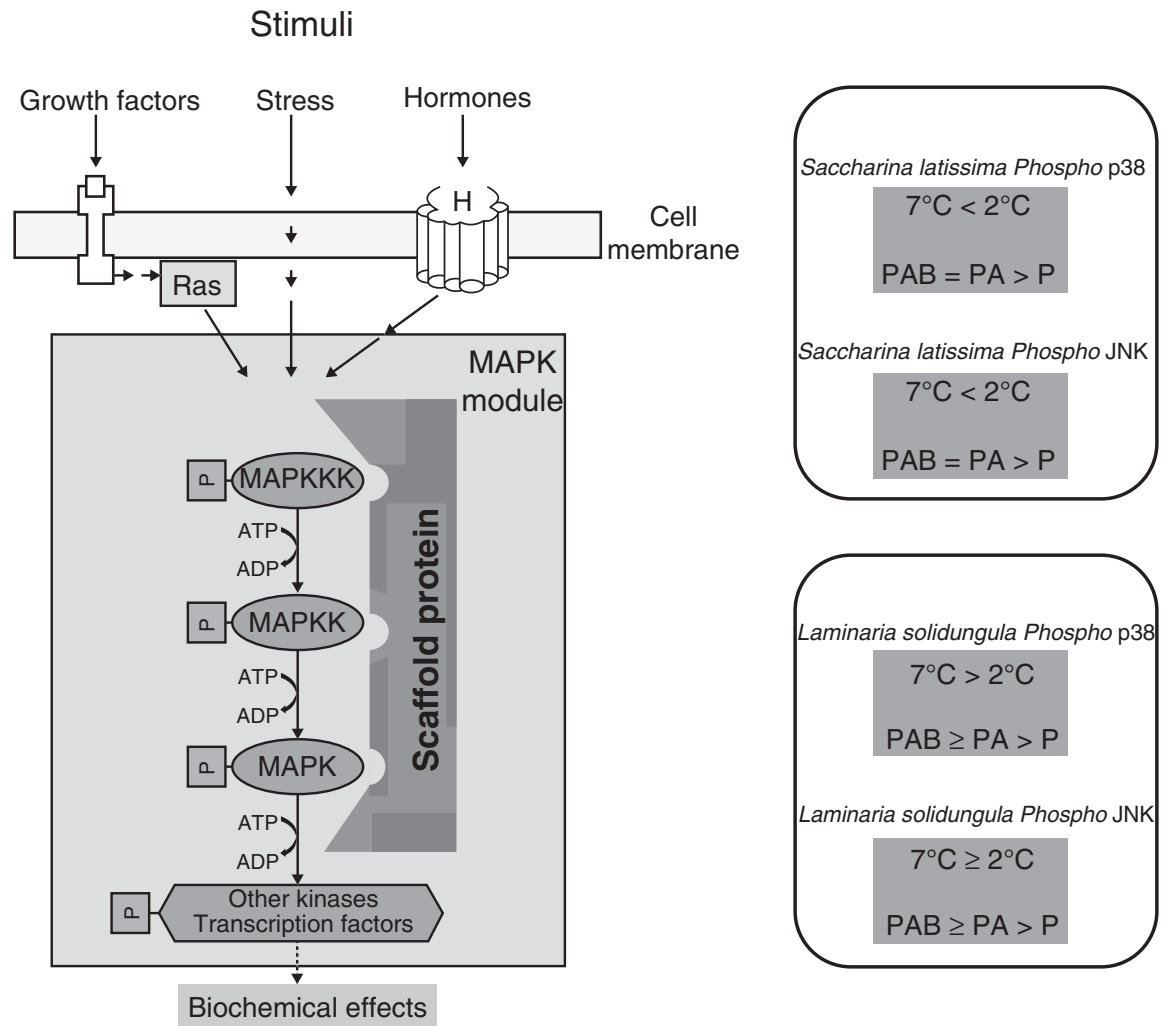

Fig. 10.4 General description of a MAPK module, with indication of its activation from the external stimuli to the biochemical effects (left panel). Ras refers to a family of GTPase proteins, which when activated by an external signal subsequently activate other proteins downstream in the signal cascade by phosphorylation. Right panel: Summary of a case study of the activation of p38 and JNK in Saccharina latissima (top) and Laminaria solidungula (bottom) in response to increased temperature (from 2 to $7{ }^{\circ} \mathrm{C}$ ) and UVR (5.01 W m $\mathrm{WVA}^{-2} \mathrm{UVA}$ and $0.48 \mathrm{~W} \mathrm{~m}^{-2} \mathrm{UVB}$ ). (Re-drawn and modified from Krauss (2008) and Parages et al. (2013))

expression profiling in kelps, e.g. examining expression profiles under changing abiotic factors or across geographical gradients, are still scarce. Heinrich et al. (2012b, 2015) investigated gene expression under multiple abiotic stressors in Saccharina latissima; Konotchick et al. (2013) analysed four Macrocystis pyrifera transcriptomes across the water column and seasons. Another two studies compared transcriptomes of Saccharina japonica under specific light quality in order to examine light regulated gene expression (Deng et al. 2012; Wang et al. 2013).

In genome-wide gene expression studies of Saccharina latissima from Kongsfjorden, Heinrich et al. (2012b, 2015) analysed gene expression profiles in response to different combinations of PAR, UVR and temperatures. Furthermore, a 
study on comparative gene expression analysis in field vs. laboratory-grown sporophytes was carried out. These studies showed that S. latissima responds to abiotic stress with a multitude of transcriptional changes, and high temperature and high PAR had stronger effects on gene expression than low temperature and low light. These results are in agreement with physiological studies showing that $S$. latissima is well adapted to low temperature and low light conditions (Bolton and Lüning 1982; Dunton 1985; Davison and Davison 1987; Hanelt 1998). Main temperature effects on the molecular level were induction of genes associated with the glycine, serine and threonine metabolism in response to low temperature, and repression of transcripts encoding carbohydrate biosynthetic and catabolic processes at high temperature. A crucial acclimation process to high PAR in S. latissima constitutes regulation of photosynthesis, e.g. induction of components of photosystem I/II, thylakoid proteins, as well as regulation of light-harvesting complex proteins (LHCs). The molecular data support former studies, showing that changes in light availability and temperature, as well as the age of the thalli, influence the pigment content and composition in S. latissima (Davison et al. 1991; Machalek et al. 1996; Hanelt et al. 1997). In addition, high PAR caused induction of catabolic processes for energy supply, heat shock proteins and ROS (reactive oxygen species) scavenging enzymes. The regulation of various ROS scavenging enzymes in response to multiple stressors demonstrates the crucial role of ROS metabolism in acclimation to abiotic stress in S. latissima. Here, the molecular data indicates a compartment-specific regulation of ROS defence. Another critical component of the molecular acclimation mechanisms to excessive light in S. latissima seems to be the induction of the vitamin $\mathrm{B}_{6}$ metabolism. Vitamin $\mathrm{B}_{6}$ exhibits antioxidant activity comparable to that of vitamins $\mathrm{C}$ and $\mathrm{E}$. For this reason, Vitamin $\mathrm{B}_{6}$ is suggested to play an important role in protecting cells from oxidative stress (Ehrenshaft et al. 1999). Gene expression profiling in S. latissima showed that acclimation to UVR includes enhanced regulation of genes encoding photosynthetic components and ROS scavenging enzymes, short acclimation to UVR furthermore comprises enhanced regulation of DNA replication and DNA repair. The combination of the stressors through high PAR, and UVR caused interactive effects on photosynthesis and gene expression (Fig. 10.5). The combination of high temperatures with high light intensities caused the strongest response and proved most harmful for the alga, leading to strong repression of crucial metabolic processes, e.g. photosynthesis and amino acid metabolism. Comparisons of gene expression profiles in field and cultivated sporophytes of S. latissima showed that principal effects of UVR were similar in culture and field sporophytes, indicating that laboratory experiments are well suited for investigating basic molecular mechanisms of acclimation to abiotic stresses. However, field material of $S$. latissima reacted less strongly than laboratory cultures, i.e. by a lower number of regulated genes, indicating that the severity of transcriptomic responses in the field may be over-estimated from laboratory experiments (Heinrich et al. 2016). 


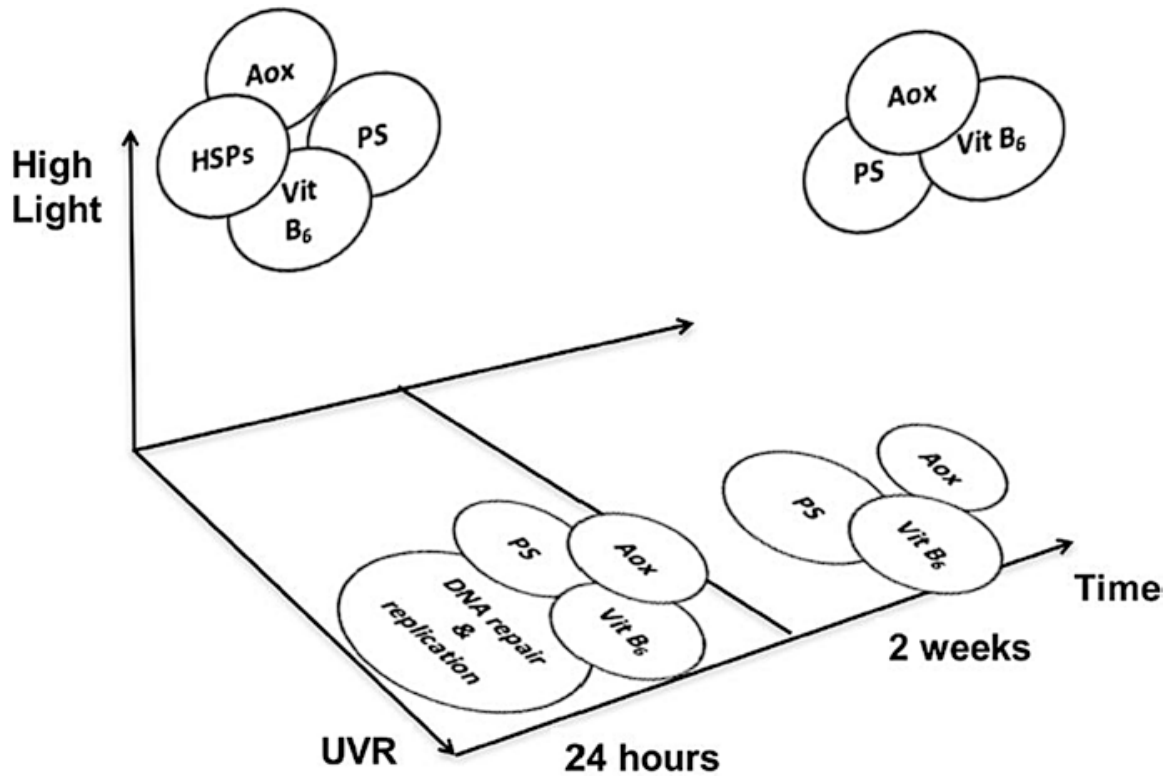

Fig. 10.5 Main molecular acclimation processes in Saccharina latissima induced by high PAR and UVR (Aox Antioxidative enzymes, HSPs heat shock proteins, PS photosynthesis, Vit $B_{6}$ vitamin $\mathrm{B}_{6}$ metabolism. (Compiled from Heinrich et al. 2012b, 2015))

\subsubsection{Eco- and Stress Physiology}

Genetic control provides the frame for physiological responses in an altered environment. Depending on their response time and the extent of metabolic and genetic change required, those adaptive reactions are distinguished as regulation (as an immediate response), acclimation (as an adjustment in physiology being active over days or weeks) or adaptation (over multiple generations and requiring changes in the genome; Hurd et al. (2014)). Beyond the limitations of such acclimatory reactions, virtually any physico-chemical variable may provoke (transient or chronic) physiological stress, which may ultimately result in cellular damage or death of the individual. In order to use physiological responses as a proxy for kelp susceptibility under climate change scenarios, a multitude of combined field and laboratory experiments has been conducted at Kongsfjorden. Field-collected samples reveal the current adaptive state of an organism at its specific growth site, while lab experiments are suitable to unravel the limits of acclimation and the interaction of multiple stress factors (Fredersdorf et al. 2009). The priority of ecophysiological research on kelps of Kongsfjorden has been placed on photophysiology, i.e. light utilisation, photoinhibition and susceptibility to ultraviolet radiation. Photosynthetic performance is widely used as an indicator for plant fitness, as virtually all kinds of physico-chemical stressors will ultimately affect proper photosynthetic functions. This is frequently connected to the generation of reactive oxygen species (Bischof and 
Rautenberger 2012), which may result in the photooxidation of cellular components but is also considered as part of signal transduction pathways (Mackerness et al. 1999). Thus, the investigation of the reactive oxygen metabolism and its significance for the sensing of and release from abiotic stress remains a relevant research task also in Arctic kelp species.

With respect to kelp photophysiology, the responses to different irradiances of PAR and the effect of ultraviolet radiation should be carefully distinguished. As both spectral ranges may induce quite different genetic responses (see Sect. 10.4.2), also the physiological effects in response to high irradiances of both differ largely. However the phenological outcome, i.e. the inhibition of photosynthetic primary reactions, may be quite similar (Bischof et al. 2002a). In this respect, rapid and sometimes superficial assessments of photosynthetic performance of kelps should be carefully evaluated. The widely used non-invasive and fast measurement of maximal quantum yield of photosystem II by monitoring pulse-amplitude modulated chlorophyll fluorescence provides a good indicator of the efficiency of energy transfer from photosynthetic antenna systems to the reaction centres and may thus be used as an easy-to-measure fitness indicator (Schreiber et al. 1994). However, sole measurements of maximal quantum yield (the ratio of variable to maximum fluorescence; $\mathrm{Fv} / \mathrm{Fm}$ ) do not allow for any interpretation on the physiological bases of observed changes. In general, observing the dynamics of change in $\mathrm{Fv} / \mathrm{Fm}$ is much more insightful, particularly as restored $\mathrm{Fv} / \mathrm{Fm}$ values after a stress event indicate recovery (Hanelt 1998). Observing the dynamics of recovery allows for discrimination of damaging versus regulatory processes in kelp physiology, which are both associated with more or less transient reductions in Fv/Fm.

From the multitude of investigations conducted on photosynthetic responses of kelp sporophytes from Kongsfjorden, the most striking findings are highlighted below:

With respect to the impact of PAR (without UV), most of the kelps show a remarkable regulatory ability to respond to transient high light stress by dynamic photoinhibition (Hanelt 1998). This phenomenon is related to the depth distribution of the respective species and, thus, represents an adaptive feature to the in situ light climate. Overall, the depth gradient as a determinator of underwater light availability (Hanelt et al. 2001) is an effective modulator of kelp photosynthetic efficiency, capacity and UV-susceptibility (Bischof et al. 1998a, b). It has also been shown that photosynthesis in the winged kelp Alaria esculenta can be "hardened" against the harmful impact of UVR within 3-5 days by repeated exposure to moderate irradiances of UV (Bischof et al. 1999). Such increase in UV-tolerance can also be observed in Saccharina latissima as part of its acclimation towards a seasonally changing radiation climate, as specimens displayed high UV-susceptibility when collected early in spring under the sea ice, and progressively increased tolerance towards the summer (Bischof et al. 2002b). Thus, overall UVR sensitivity among different Arctic kelp species is related to their depth distribution (see Sect. 10.2) and corresponding light history at the respective depth (Wiencke et al. 2000, 2006; Roleda et al. 2006d, 2010). 
Evidently, other environmental factors, such as temperature, do modulate stress responses and may either act synergistically, but also in an antagonistic way. For example, it has been shown that temperatures up to $13{ }^{\circ} \mathrm{C}$ (well above the ambient SST in Kongsfjorden) may compensate for inhibitory UV-effects of maximal quantum yield in Alaria esculenta (Fredersdorf et al. 2009). This becomes understandable when taking into account the geographic spread of A. esculenta with a Southern distribution limit in Brittany, which implies that the population at Svalbard currently still thrives under permanent suboptimum temperatures. Overall, by linking our knowledge on stress perception (Sect. 10.4.1), gene expression (Sect. 10.4.2) and individual ecophysiology (this section) we already receive a quite complete picture on the wide range of mechanisms and capacity of acclimatory features applied by kelps in order to respond to and endure in a changing environment. Conclusively, it is likely that those kelps, which populate Kongsfjorden and have their main distribution in somewhat lower latitudes, will rather perform better under scenarios of temperature increase in the Arctic (Krause-Jensen and Duarte 2014). This is also suggested in the modelling study by Müller et al. (2009a), which, based on a combination of temperature tolerance data and predictions of changes in sea surface temperature, implies future northern range expansion and increased productivity of those kelp species inhabiting Kongsfjorden. In contrast, for the endemic, and strictly cold-adapted kelp Laminaria solidungula a retreating distributional range is very likely.

The above-mentioned studies have been mostly conducted on the adult, sporophyte phase of kelps. As we will see below, other developmental stages of kelp, and in particular the microscopic spores, may reveal specific and pronounced differences in stress susceptibility (Sect. 10.4.5). Although the multitude of ecophysiological studies have considerably advanced our understanding of the mechanisms of functional responses of kelps towards most abiotic stressors, still such studies do not allow for evaluating the capacity for adaptation. Studying adaptation in macroorganisms is tricky business, as genetic adjustments need to be studied over a series of generations. Thus, the central question of whether adaptive adjustments in kelp physiology keep up with the pace of environmental change remains to be addressed.

\subsubsection{Cellular Ultrastructure}

Investigation of the cellular structure of different life history stages of kelps is vital to understand development and survival of the species. Already 50 years ago electron microscopy was used to describe cellular features of brown algae, firstly from temperate regions (Bouck 1965). However, to our knowledge, detailed analyses of cellular structures of kelp thalli from Kongsfjorden have been made only for $S$. latissima (Hanelt et al. 1997; Holzinger et al. 2011) and A. esculenta (Lütz et al. 2016). In case of Laminaria hyperborea from Helgoland (Steinhoff et al. 2008) and S. latissima from Kongsfjorden (Steinhoff et al. 2011a), the ultrastructural features of zoospores and developing gametophytes have been characterized. Despite the 
species-specific growth habits of the adult sporophytes, the ultrastructure of the spores shares several general features: one chloroplast per cell, a large and dominating nucleus, large lipid globules, dictyosomes and several small mitochondria. The fate of the lipid storage was followed in spores from S. latissima from Kongsfjorden during development into gametophytes (Steinhoff et al. 2011a). The lipid globules changed electron density during spore germination, which could be explained by changes in fatty acid composition. The turnover of lipid material continued until the chloroplasts took over most of the energy formation. The few small physodes, vesicles containing the phenolic compound phlorotannin, did not change under applied UV-stress, but major changes were described for the nucleus. Whether physodes in this stage of development are able to protect from UV-stress remains unclear as A. esculenta spores from Kongsfjorden may exudate phlorotannins to the surrounding medium as a photo-protective feature. Additionally, the cellular physodes are unevenly distributed in the cells and may thus only marginally protect against UV radiation (Wiencke et al. 2007).

Most physiological studies were performed with the fully developed phylloid, preferentially to follow different photosynthetic activities and to perform analyses of e.g. proteins and other constituents. A light microscopic overview for A. esculenta is given in Lütz et al. (2016) showing the typical anatomical structure of leathery thalli of brown algae. A similar tissue organization can be found in S. latissima from Kongsfjorden (Holzinger et al. 2011), but also in Ecklonia radiata from Australia (Lüder and Clayton 2004) or Sargassum cymosum from Brazil (Polo et al. 2014). Figure 10.6a shows for A. esculenta the meristodermal layer with smaller cells containing most of the plastids, and thick outer walls. Frequently dictyosomes appear, often close to the nuclear envelope (Fig. 10.6c), which was already marked by Bouck (1965). Less often lipid droplets (Fig. 10.6d) can be seen. An effective compound transport can be assumed by the regularly visible plasmodesmata (Fig. 10.6e,f) as suggested also for S. latissima and L. hyperborea (Schmitz and Kühn 1982).

The ultrastructure does not change in samples taken from a depth range of 3-10 m (own observations), but further studies of possible depth influence are required because, especially, the light regime changes drastically. Neither in $S$. latissima nor in A. esculenta could we observe any aggregated material for proteinor carbohydrate-storage (comparable to starch grains or protein crystals). When carbohydrate storage occurs, an amorphous accumulation of laminaran e.g. in the vacuoles of medulla or cortex cells may be assumed. The cortex cells contain only few plastids and the inner medulla is free of most organelles. Based on the number of organelles in the cells visible by transmission electron microscopy (TEM), one can estimate that roughly $90 \%$ of the metabolic, especially photosynthetic, activity takes place in the meristodermal layer and the adjacent outer layer of the cortex.

Under exposure to elevated UVA plus UVB radiation only chloroplasts show a response in ultrastructure, while all other cell organelles remain unchanged at least in membrane appearance (Holzinger and Lütz 2006; Holzinger et al. 2011; Lütz et al. 2016). An example of disturbed thylakoid structure under PAR+UVA/B is given in Fig. 10.6b. Such membrane dilations are a typical, but not a specific sign of UV-damage. Other stresses like copper on S. latissima (Brinkhuis and Chung 1986), 


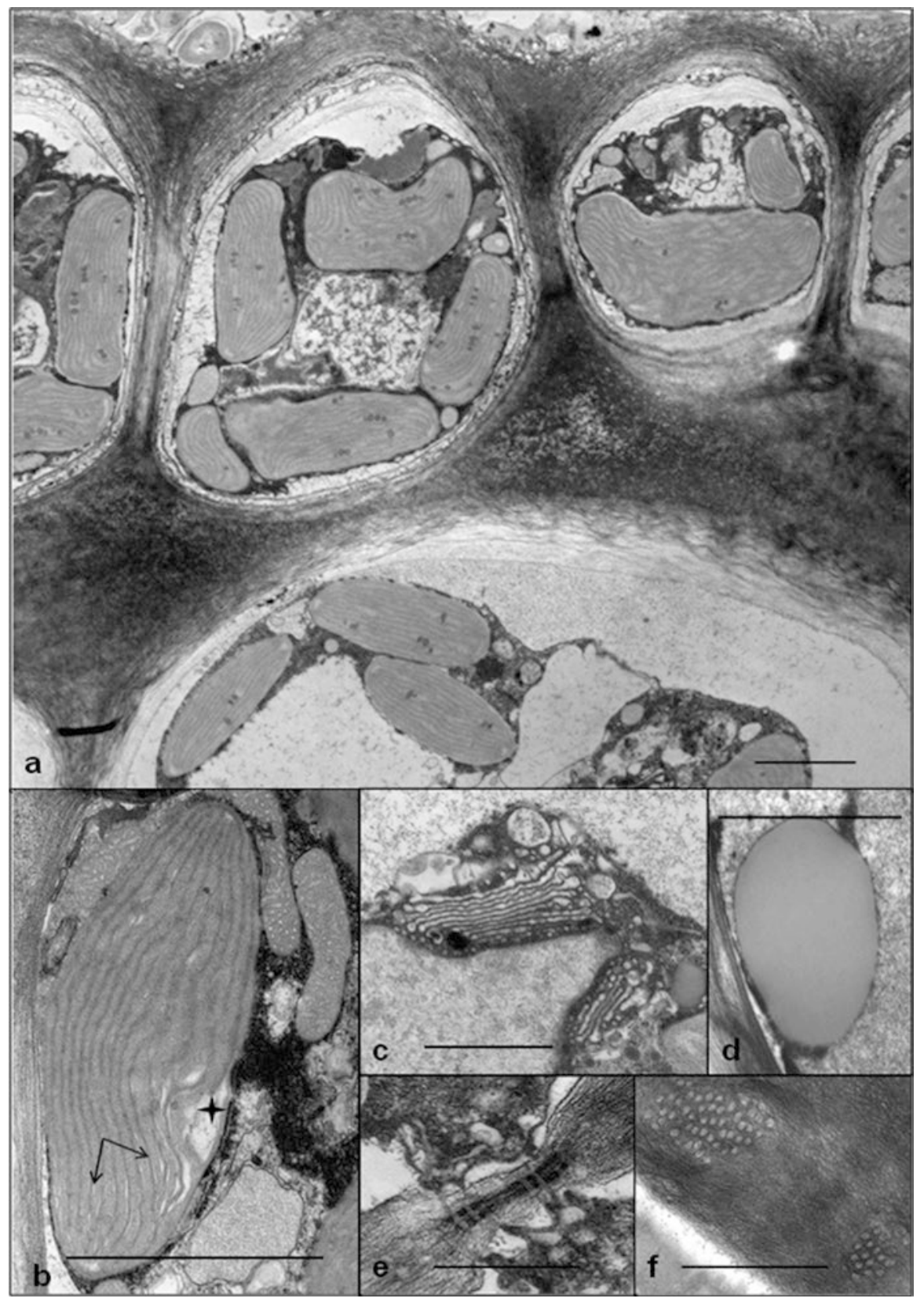

Fig. 10.6 Ultrastructure and cellular details of Alaria esculenta from Kongsfjorden. (a) Part of the meristodermal layer and a large cortex cell of the phylloid. (b) Thylakoid dilations after PAR+UV-A/B treatment (arrows). Star: DNA region of the plastid. The large mitochondria remain unaffected. (c) Two dictyosomes flanking a part of the nucleus, a constellation frequently observed. (d) Lipid droplet, probably containing neutral lipids because of the greyish staining. (e, f) Plasmodesmata between meristodermal cells shown in two different section planes. For details on sample preparation and transmission electron microscopy (TEM) methods see Lütz et al. (2016). Scale bars: a, b, d: $2 \mu \mathrm{m}$; c: $1 \mu \mathrm{m}$; e, f: $500 \mathrm{~nm}$ 
or $\mathrm{SO}_{2}$ on higher plant leaves (Schiffgens-Gruber and Lütz 1992), generate comparable membrane damage as well. The interpretation of UV-effects is difficult on the ultrastructural level, because the phylloid is mostly exposed to a solar input of diffuse and scattered radiation at the growth site and not in a more or less perpendicular angle like in simulation experiments.

Nevertheless, UV-effects in simulation studies on ultrastructure and photosynthetic parameters as well as recovery experiments have shown that algae from shallow waters can be affected, but not in a lethal way, i.e. for A. esculenta and Saccorhiza dermatodea (Bischof et al. 1998a, Wiencke et al. 2004, Roleda et al. 2006a). In contrast kelp species from deeper sites like L. solidungula or S. latissima may be seriously affected not only by higher short-wave, but also by higher PAR exposure (Karsten et al. 2001; Wiencke et al. 2004, 2006; Roleda et al. 2010; Bischof and Steinhoff 2012).

The interpretation of the role of physodes and similar phlorotannin containing, often globular structures, is connected with the question whether UVR results in a stress or a strain. Larger physodes can easily be detected by light microscopy after staining, like in Holzinger et al. (2011) for S. latissima from Kongsfjorden. Their cellular distribution can only be viewed in TEM and is well described for a number of brown algae (Schoenwaelder 2002; Lüder and Clayton 2004). Often the role of physodes is interpreted as an effective UV-shield, because their molecular properties support this idea. However, their uneven and in general not surface-oriented distribution in the thallus cells does not underpin a primary shielding function. Recently, Halm et al. (2011) showed for L. hyperborea that phlorotannins are inducible by PAR alone, and by PAR + UVA/UVB radiation, which points towards their function as photoprotective compounds. In addition, phlorotannins are induced by mechanical wounding to simulate herbivory (see also Amsler and Fairhead 2006).

In the cytological studies with S. latissima and A. esculenta (Holzinger et al. 2011; Lütz et al. 2016) no UV-dependent changes in amount or localization of physodes or putative phlorotannin containing vesicles could be found. Even in the sensitive stage of zoospore formation, UV does not induce phlorotannin accumulation in Arctic Laminariales (Steinhoff et al. 2008; Müller et al. 2009b), but induction phenomena and a possible multiple role of physodes deserve more detailed investigations.

When studying the meristodermal layer e.g. in case of A. esculenta it was surprising that larger areas of the outer cell wall show many, and structurally very different, biota (Fig. 10.7). From size and structure of these attached organisms it may be assumed that they are bacteria or small fungi. The occurrence of such biota on brown algae, but also other marine algae worldwide, is summarized by Friedrich (2012) and by Potin (2012). In Fig. 10.7 (c, d), the arrows point to many small physode like globules which accumulate in the cell wall opposite to the "epiphytes". Other globules can be found outside the cell wall close to these organisms, and the meristodermal cells contain large amounts of phlorotannins. Similarly, Schoenwaelder and Clayton (1998) describe for zygotes from Australian brown algae, that physodes "are secreted into the primary zygote wall", and Schoenwaelder (2002) mentioned reports about physodes in the cell wall of brown algae. As is dis- 


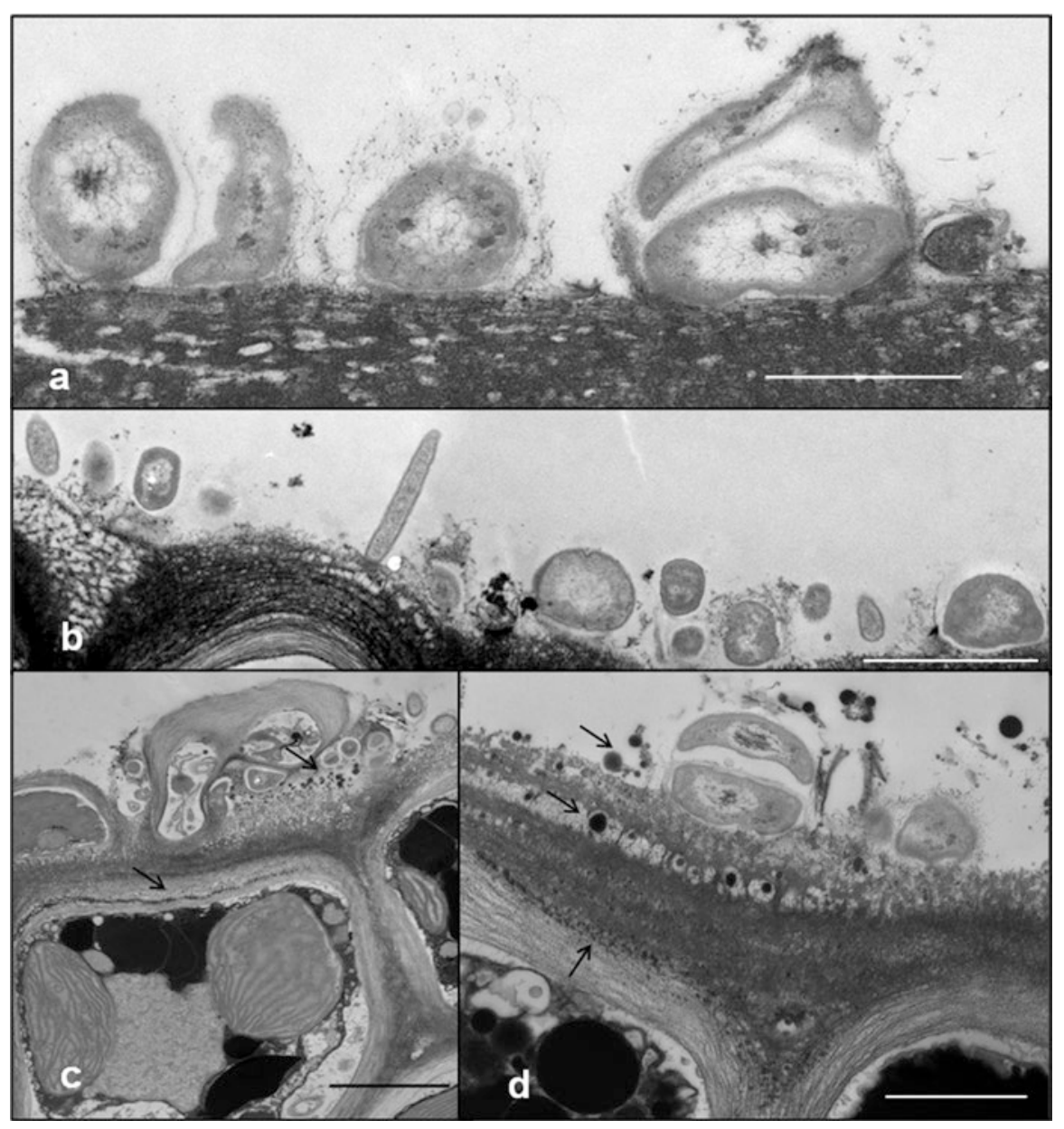

Fig. 10.7 Different appearances of microbial organisms growing on or adhering to the thallus surface of Alaria esculenta. Species identification was not possible. Arrows (c, d): accumulation of phlorotannin like material in the outer cell wall and in the matrix outside. Scale bars: a $0,5 \mu \mathrm{m}$; b, d $1 \mu \mathrm{m} ; \mathbf{c} 2 \mu \mathrm{m}$

cussed in Lütz et al. (2016), one important role of phlorotannins may be reduction of such probably pathogenic microbial activities. This supports the findings of Amsler and Fairhead (2006) discussing phlorotannins as defence compounds. A related aspect is presented by Lüder and Clayton (2004), Halm et al. (2011) and Falkenberg et al. (2014), who defined the role of phlorotannins as protectors against herbivory.

Figure 10.7 indicates another interesting structural aspect: several of the small bacterial-like structures or the phlorotannin globules do not have any visible connection to the cell wall. Normally, they would have been removed completely by the numerous washing and incubation steps during fixation for TEM, if they were only 
slightly attached. We, thus, assume the presence of a non-stainable thin matrix outside the cell wall, which is probably stabilized by glutaraldehyde crosslinking (proteins) fixation. Here further studies are required.

Other open questions regarding the structural features of kelp species are, whether strong changes in salinity induced by glacier melting, enhanced oxidative stress loads or the winter situation change tissue and cellular internal structures, either as adaptation or in a possible deleterious way.

\subsubsection{Impacts of Stress on Various Developmental Stages, Tissue Types, and Implications for Growth \& Reproduction}

The reaction of kelps to the abiotic variables, which finally determine their performance (fitness) in the ecosystem, depends on the balance between the stimulating and inhibiting effects of the diverse environmental variables. In this respect, growth and reproduction are key parameters integrating responses of the various molecular and physiological mechanisms described above to changes in the abiotic environment.

The heteromorphic life-cycle of kelps has been introduced in Sect. 10.1 and basically entails the macroscopic and diploid sporophyte producing haploid spores to give rise to the microscopic and haploid gametophytes, which produce gametes. Once released, these fuse to form a zygote, from which the sporophyte develops. It is evident, that all these different generations and developmental steps are under control of the physical environment and may all have individual optimum conditions.

Arctic and cold-temperate seaweeds experience pronounced seasonal changes in water temperature, light quantity and quality. A species' physiological optimum and upper survival temperature are known to be higher than in its natural environment. For example, the optimum quantum yield of meiospores' photosynthesis of various Arctic kelp species was maximal between $7-13{ }^{\circ} \mathrm{C}$ and lowest at $2{ }^{\circ} \mathrm{C}$ (Roleda 2009). Gametophytes of Arctic to cold-temperate species survive temperatures of 19-20 ${ }^{\circ} \mathrm{C}$ (tom Dieck 1993). For the diploid life stage, growth rates of endemic Arctic Laminaria solidungula sporophytes were comparable at $0{ }^{\circ} \mathrm{C}, 5^{\circ} \mathrm{C}$ and $10{ }^{\circ} \mathrm{C}$ (Wiencke and Fischer 1990); the main difference is that growth under $0{ }^{\circ} \mathrm{C}$ is saturated already at lower light intensity $\left(20 \mu \mathrm{mol}\right.$ photons $\left.\mathrm{m}^{-2} \mathrm{~s}^{-1}\right)$ compared to $5-10{ }^{\circ} \mathrm{C}\left(55-60 \mu \mathrm{mol}\right.$ photons $\left.\mathrm{m}^{-2} \mathrm{~s}^{-1}\right)$. Growth of the sporophyte of this species is possible up to $15^{\circ} \mathrm{C}$, the upper survival temperature (UST) is $16^{\circ} \mathrm{C}$ (tom Dieck 1992). Sporophytes of S. latissima and L. digitata grow between 0 and $20{ }^{\circ} \mathrm{C}$ and exhibit UST's of 20 or $21^{\circ} \mathrm{C}$ (Wiencke et al. 1994).

At the other end of the spectrum, most species of the Arctic and cold-temperate gametophytes tested were able to survive the lowest tested survival temperature of 0-1 ${ }^{\circ} \mathrm{C}$ for more than a year of total darkness (tom Dieck 1993). The sporophytes of 
endemic Arctic L. solidungula are also able to survive 7 months of continuous darkness with positive but minimal growth (Henley and Dunton 1997). High PAR in excess to their photosynthetic requirement can also be damaging. Gametophytes of the Arctic - cold-temperate $L$. digitata are less sensitive to high PAR (500 $\mu \mathrm{mol}$ photons $\mathrm{m}^{-2} \mathrm{~s}^{-1}$ ) compared to corresponding sporophytes (Hanelt et al. 1997). Relative to the age and size class of the sporophytes, the capacity to cope with high PAR increases with increasing age of the thalli (Hanelt et al. 1997).

The effects of UVA and UVB radiation on growth have been studied in various kelps from Kongsfjorden. Growth rates in Laminaria digitata, Saccharina latissima and Saccorhiza dermatodea collected in the field and exposed in July at the water surface are significantly inhibited by UVR. There was, however, no significant difference between individuals exposed to PAR (P), PAR + UVA (PA) and $\mathrm{PAR}+\mathrm{UVA}+\mathrm{UVB}(\mathrm{PAB})$ and full solar radiation (Aguilera et al. 1999). In contrast, this effect was demonstrated by Michler et al. (2002) in Alaria esculenta in the laboratory. The effect of PA was relatively small, however, additional UVB resulted in a considerable reduction of the growth rate. The effect of PA was much stronger in the undergrowth- and deep-water species $L$. solidungula, compared to the more sunlight-adapted A. esculenta. Additional UVB led to tissue necrosis after only a few days of exposure indicating for the first time that the effect of UVR on growth may be correlated to depth distribution.

Similar results were obtained by Roleda et al. (2005a, 2006b): Growth rates of very small sporophytes (initial size $30 \mathrm{~mm}^{2}$ ) exposed to $\mathrm{PAB}$ in the laboratory decreased successively from $A$. esculenta, over $L$. digitata and $S$. latissima to $L$. solidungula (Fig. 10.8). Interestingly, a considerable acclimation potential was found in A. esculenta and $L$. digitata. This pattern closely corresponds to the depth

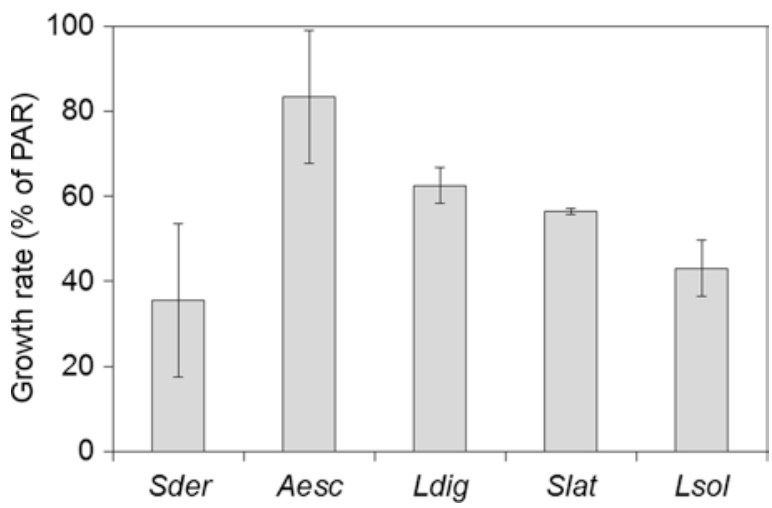

Fig. 10.8 Growth rates of juvenile Arctic kelp species under the full radiation spectrum (PAR+UVA+UVB) expressed as percent of their respective PAR controls. Species are Saccorhiza dermatodea (Sder), Alaria esculenta (Aesc), Laminaria digitata (Ldig), Saccharina latissima (Slat) and Laminaria solidungula ( Lsol) grown under $8{ }^{\circ} \mathrm{C}$ and $16: 8$ light-dark photoperiod of $3.6 \mathrm{~W} \mathrm{~m}^{-2} \mathrm{PAR}$, and 6 hours UVR in the middle of the light phase consisting of $4.92 \mathrm{~W} \mathrm{~m}^{-2} \mathrm{UVA}$ and $0.41 \mathrm{~W} \mathrm{~m}^{-2} \mathrm{UVB}$. Bars are means $(\mathrm{n}=3 ; \pm \mathrm{SD})$. (Compiled and modified from Roleda et al. 2005a, 2006b)) 
distribution described for this time period by Hop et al. (2012; see Sect. 10.2) and corresponds to results obtained on three kelp species from Helgoland (North Sea; Roleda et al. 2006c). The only species not fitting into this pattern is $S$. dermatodea (Fig. 10.8). This species exhibits the lowest growth rate of all species under the full radiation spectrum although it occurs together with A. esculenta and L. digitata in shallow waters. So this species obviously takes a loss when exposed to excessive $\mathrm{PAB}$ in shallow waters. On the other hand germinating spores of this species are extremely tolerant to PAB as we will see below.

Spores are the life-history stage of kelps most susceptible to environmental perturbations. Relative to light quality, the early life-history phases of kelps are also more susceptible to UVR compared to their respective adult life stages (Roleda et al. 2007; Fredersdorf et al. 2009). When exposed in the laboratory to PA, spore germination of kelps from southern Spain, Helgoland and Kongsfjorden was inhibited considerably, and after exposure to additional UVB even more so (Wiencke et al. 2000, 2004; Roleda et al. 2005b). The degree of inhibition was highest in deep-water and undergrowth species. The species from Kongsfjorden strongly affected by PAB were $L$. solidungula, $S$. latissima and $L$. digitata (Wiencke et al. 2004; Roleda et al. 2010). In contrast, A. esculenta and $S$. dermatodea were much less affected by exposure to the full spectrum (Wiencke et al. 2004, 2007, Roleda et al. 2006a) and there was a potential for recovery from PAB-induced damage during post culture without UVR in A. esculenta. In S. dermatodea, Wiencke et al. (2004) demonstrated even a full recovery. Again, this pattern mirrors quite nicely the depth distribution described by Hop et al. (2012; Sect. 10.2).

Direct comparison between mature and young field-collected Arctic Saccharina latissima and meiospores released from fertile samples, showed highest sensitivity to PAR and PAR+UVR in meiospores and lowest in mature sporophytes compared to control (dim white light; Fig. 10.9). However, positive carry-over effects from reproductive adults inhabiting high-UV environments onto the next generation of meiospores have been reported among kelps. Meiospores of kelps released from adults growing under low-UV environments are more susceptible to UV-stress experiments in the laboratory compared to progeny of adult kelps from high-UV environments (Swanson and Druehl 2000). This indicates ecotypic acclimation and adaptation under high-UV environments (Hanelt and Roleda 2009).

In field experiments, the tolerance of spores to the full solar spectrum was highest in the shallow water species $S$. dermatodea, intermediate in the upper to mid sublittoral A. esculenta and lowest in the upper to mid sublittoral L. digitata (Wiencke et al. 2006). Unexpectedly, there was no difference in the susceptibility of spores exposed to ambient solar radiation compared to solar radiation depleted of UVB, as known from laboratory experiments. Nevertheless, UVR tolerance is a major, probably even one of the most important factors determining the upper distribution limit of kelps on the shore (Bischof et al. 2006). This becomes particularly obvious when comparing the relationship between effective UVB dose and germination rate (Fig. 10.10).

However, the UVR susceptibility of spores changes seasonally. Steinhoff et al. (2011b) demonstrated a strong inhibition of spore germination in $S$. dermatodea 


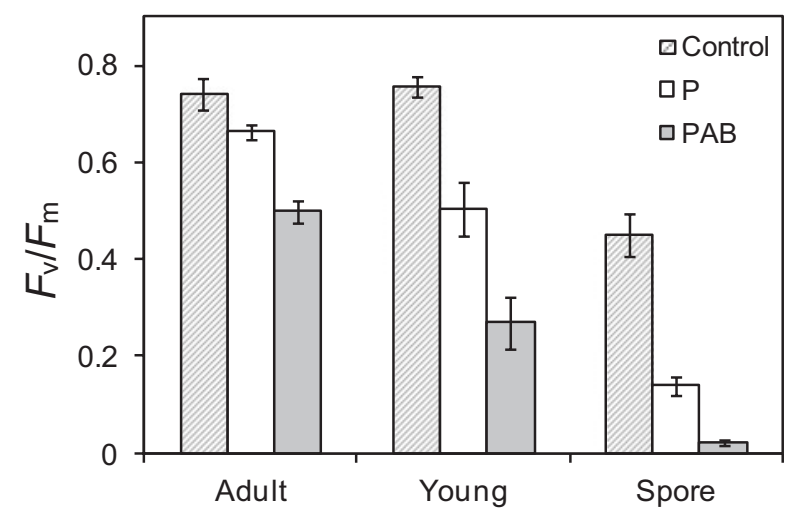

Fig. 10.9 Optimum quantum yield of photosynthesis (Fv/Fm) of Saccharina latissima vegetative sporophytes (adult and young) and meiospores released from fertile samples after 2 hours exposure under PAR (P) and PAR+UVA+UVB (PAB) at $2{ }^{\circ} \mathrm{C}$. PAR $=22 \mu \mathrm{mol}$ photons $\mathrm{m}^{-2} \mathrm{~s}^{-1}$, $\mathrm{UVA}=6 \mathrm{~W} \mathrm{~m}^{-2}, \mathrm{UVB}=0.45 \mathrm{~W} \mathrm{~m}^{-2}$. Control $=4 \mu \mathrm{mol}$ photons $\mathrm{m}^{-2} \mathrm{~s}^{-1}$. Bars are mean $\pm \mathrm{SD}$ $(\mathrm{n}=6)$. (Roleda, Gómez and Huovinen, unpublished data)

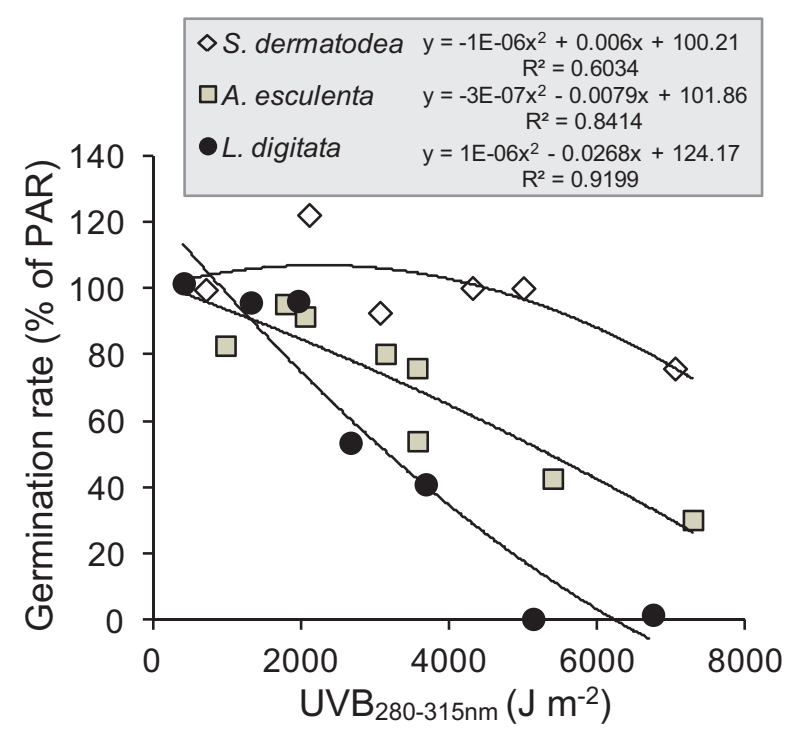

Fig. 10.10 Dose-response curves for Saccorhiza dermatodea, Alaria esculenta and Laminaria digitata. Germination rate under PAR+UVR expressed as percent of PAR after exposure of spores to in-situ radiation at different depths in Kongsfjorden. Figure modified from Wiencke et al. (2006); $\mathrm{UVB}_{280-315 \mathrm{~nm}}$ dose calculated after McKenzie et al. (2004). UVB $280-315 \mathrm{~nm}$ doses needed to achieve $50 \%$ inhibition of germination are $>7550 \mathrm{~J} \mathrm{~m}^{-2}, 5285 \mathrm{~J} \mathrm{~m}^{-2}$ and $3156 \mathrm{~J} \mathrm{~m}^{-2}$ for $S$. dermatodea, A. esculenta and L. digitata, respectively 
exposed to ambient solar radiation in August. This contrasts sharply to the results obtained in the above mentioned field study by Wiencke et al. (2006), who found no differences between the germination under solar radiation depleted of UVR and the full solar spectrum even at the low water depth of $0.5 \mathrm{~m}$. Similar seasonal changes in the UVR susceptibility of kelp spores were found also in laboratory experiments with kelps, especially in studies investigating the interactive effects of environmental variables (see below).

Besides UVR, also temperature has strong effects on germination. Spores of $S$. dermatodea, A. esculenta, $L$. digitata and S. latissima germinate optimally at temperatures between 2 and $12{ }^{\circ} \mathrm{C}$. Exposure to $17{ }^{\circ} \mathrm{C}$ inhibits spore germination slightly in S. dermatodea and $18{ }^{\circ} \mathrm{C}$ is lethal for the latter three species (Müller et al. 2008; Steinhoff et al. 2011b).

The interactive effects of elevated temperatures and UVR have been examined in several studies. Germination of spores from $S$. dermatodea was not inhibited by PAB at 2,7 and $12{ }^{\circ} \mathrm{C}$, but it was quite strongly inhibited at $17{ }^{\circ} \mathrm{C}$ (Steinhoff et al. 2011b). Similarly, spore germination of A. esculenta was not inhibited by PAB at 2 and $7{ }^{\circ} \mathrm{C}$ in May (Müller et al. 2008). In July, however, spores of this species exhibited a higher PAB susceptibility at $2{ }^{\circ} \mathrm{C}$ compared to $7{ }^{\circ} \mathrm{C}$ (Olischläger and Wiencke 2013). At $12{ }^{\circ} \mathrm{C}$, and especially at $16{ }^{\circ} \mathrm{C}$, germination was inhibited in this species after PAB exposure (Müller et al. 2008; Fredersdorf et al. 2009). Germination of $L$. digitata spores was very strongly inhibited under PAB exposure at $2{ }^{\circ} \mathrm{C}$ both in May and in July to September (Müller et al. 2008; Olischläger and Wiencke 2013). At $7^{\circ} \mathrm{C}$, no inhibition of germination was recorded in May (Müller et al. 2008), whereas in July to September germination was inhibited by about $50-80 \%$ in this species (Olischläger and Wiencke 2013). A comparable degree of inhibition was also demonstrated at $12{ }^{\circ} \mathrm{C}$ in May (Müller et al. 2008).

Salinity, as another important environmental variable influencing spore germination, has been tested in A. esculenta (Fredersdorf et al. 2009). At $16{ }^{\circ} \mathrm{C}$, i.e. at a temperature close to the upper survival limit, germination of spores exposed to $\mathrm{P}$ was considerably, although insignificantly, inhibited at a salinity of 20. Exposure to $16{ }^{\circ} \mathrm{C}$, salinity of 20 and PA or PAB resulted, however, in strong and significant inhibitions of germination. In summary, the responses of spores to environmental perturbations depend on the type of perturbation (radiation regime, temperature, salinity and probably other factors) as well as on the season.

When early developmental phases of kelps i.e. meiospores and microscopic sporophytes are subjected to environmental stressors, e.g. low light, low nutrients, high temperature, and UVR (e.g. Gerard 1997; Roleda et al. 2006d; Roleda 2009), the stressed samples are photoinhibited and have reduced growth rates. However, when they were allowed to recover and cultivated under control or optimal conditions, cells and sporophytes are able to recover their photosynthetic functions and growth rates are comparable to the control group (Gerard 1997; Roleda et al. 2006d; Roleda 2009). Despite the higher susceptibility of early life-history stages to environmental stressors, they are also capable of rapid recovery without negative effects persisting into the later developmental stages when the stress factors are eliminated (Gerard 1997). However, chronic and long-term exposure of juvenile kelp sporophytes to 
UVR caused morphological damage such as tissue lesions, blistering and deformation, and necrosis (Michler et al. 2002; Roleda et al. 2004), despite photosynthesis of sporophytes being able to acclimate to UVR (Roleda et al. 2004).

Sporogenic and vegetative tissue of Laminariales exhibit distinctive sensitivity to UVR (Gruber et al. 2011; Holzinger et al. 2011). Less DNA damage was observed in soral compared to non-soral tissue (Gruber et al. 2011). This could be explained by the presence of phlorotannin-containing paraphysis cells in soral tissue (see Sect. 10.4.4). These cells are found towering over the sporangia and shielding the meristoderm from UVR, thus offering protection to the UV-sensitive meiospores and different organelles e.g. mitochondria, golgi bodies, and nucleus, respectively (Holzinger et al. 2011). Moreover, soral tissues have $3 \times$ higher antiradical power (ARP) capacity compared to non-soral tissue (Holzinger et al. 2011). Among juvenile sporophytes, the susceptibility of vegetative tissue to UVR depends on thallus thickness and optical density (Roleda et al. 2005a, 2006b); whereby thinner and translucent thalli incur more DNA damage compared to thicker and highly pigmented tissue (Roleda et al. 2007).

\subsubsection{Biotic Interactions Affecting Kelp Performance}

The presence of an adult canopy of Arctic kelp species has the potential to modify stress regimes for early life stages of con- and heterospecific recruits, which may have a higher susceptibility to environmental stress than adult kelps (references in Franklin and Forster 1997, see Sects. 10.4.3 and 10.4.5). In particular the modification of understory irradiance regimes through moderate shading of an adult kelp canopy could possibly enhance germination success of zoospores of Arctic kelp species, which is suppressed under high light intensity and ultraviolet radiation as revealed by a field experiment in Kongsfjorden (Wiencke et al. 2006; see Sect. 10.4.5).

In the cold-temperate zone, Sjøtun et al. (2006) reported on reduced survival of L. hyperborea recruits under a dense adult canopy, which the authors explained by photon fluence rates that were insufficiently low for growth, ultimately killing recruits. Likewise, in the warm-temperate zone microscopic stages of L. ochroleuca did not grow under an adult canopy, but quickly replenished the canopy in areas where the canopy had been completely removed (Barradas et al. 2011), suggesting shading as a proximate cause for recruitment failure. Maternal facilitation of kelp recruitment (L. hyperborea) was also reported from moderately wave-exposed sites and where partial canopy removal from trawling or experimental manipulation had been done along the west coast of mainland Norway (Christie et al. 1998; Pedersen et al. 2012). Probably, a reduced adult canopy generates an optimal light regime for the growth of conspecific microscopic stages and juvenile sporophytes. Besides the modification of environmental conditions by conspecifics, interspecific interactions may also affect kelp recruitment. For instance, a study by Gagnon et al. (2003) indicates that kelp recruitment (Agarum cribrosum) may benefit from canopies of a non-kelp species (Desmarestia viridis). Wave-induced sweeping movements of the 
canopy keep green sea urchins (Strongylocentrotus droebachiensis) away from $D$. viridis, generating a refuge for A. cribrosum recruits. Furthermore, light regimes under kelp canopies may generate an insufficient light regime for epiphytes and algal turfs (Christie et al. 1998). The latter were shown to suppress the growth of at least macroscopic life stages of kelp (Graham 1997).

As ecosystem engineers, kelps provide habitat and/or food for numerous associated species ranging from mobile invertebrates and fish to sessile epibionts, which use kelp as substratum (Christie et al. 2009). This facilitative effect, by which diversity and presumably productivity are locally enhanced, is also true for Arctic coastal systems although their associated species assemblage is impoverished in comparison with similar habitats at lower latitudes (Rózycki and Gruszczynski 1986; Carlsen et al. 2007; Ronowicz et al. 2013). Lippert et al. (2001), for example, identified a total number of 104 faunal species associated with different kelp species in Kongsfjorden, with bryozoans and amphipods yielding the highest species number. Wlodarska-Kowalczuk et al. (2009) even detected a total of 208 species associated with a kelp forest in Hornsund, where bryozoans, polychaetes and hydrozoans represented the dominant taxonomic groups. Such close association with many organisms also implies multiple direct and indirect interactions, which may also affect the habitat-forming kelps by causing biotic stress. From temperate regions, for example, it is well known that mobile kelp-associated grazers (e.g. urchins and snails) are important drivers of kelp population dynamics (e.g. Sivertsen 1997; Sjøtun et al. 2006; Feehan et al. 2012; Iken 2012). However, grazer effects on population dynamics in Arctic kelps seem to be of minor importance due to a comparatively low number of herbivorous species at higher latitudes, which is also reflected in rather low levels of defence mechanisms against herbivores in Arctic seaweed species (Wessels et al. 2006).

Considering sessile kelp-associated species, most of them are concentrated on the holdfast of the macroalgae. In Kongsfjorden and Hornsund, kelp bed bryozoans and hydrozoans represent the most diverse taxonomic groups of epibionts attached to algal holdfasts (Carlsen et al. 2007; Ronowicz et al. 2008; Wlodarska-Kowalczuk et al. 2009). However, many colony-forming species such as bryozoans may also occur in high densities attached to stipes and blades (Rózycki and Gruszczynski 1986) and, therefore, may alter biologically relevant processes at the kelp-seawater interface (e.g. nutrient uptake). Additionally, when calcified, these encrusting epibionts may change mechanical thallus properties (e.g. flexibility), which can lead to increased susceptibility to breakage. This may negatively affect kelp population dynamics, especially when many blades break below the intercalary meristems of the algae. In this context, it has been suggested that crusts of bryozoans may also reduce kelp growth and promote premature senescence and fragmentation during storms (Lampert et al. 1992). Additionally, it is reported that encrusting colonial epibionts reduce spore release of overgrown kelps (Saier and Chapman 2004), and all of these effects can place stress on kelp populations.

Knowledge about intraspecific kelp interactions such as competition is missing for Arctic habitats. Moreover, most of the interspecific interactions between kelps and their associated organisms have been examined at lower latitudes and knowledge 
on Arctic kelps is extremely scarce. Currently, it seems that neither grazing by herbivores nor overgrowth by epibionts strongly affects the kelp population dynamics but experimental evidence from field studies is missing. Yet, it has been postulated that Arctic ecosystems will experience profound changes by the direct and indirect effects of global warming (IPCC 2013; Pavlov et al. 2013). A warmer Arctic is expected to lead to a spatial enlargement of Arctic kelp beds and a northward extension of many species including North Atlantic seaweed species (Krause-Jensen and Duarte 2014; Müller et al. 2009a) and also kelp-associated organisms (Bartsch et al. 2012; Wiencke and Amsler 2012; Raybaud et al. 2013). This may result in an increased number of biotic interactions within seaweed beds at higher latitudes (Weslawski et al. 2011), which is likely to alter the effects of epibionts, grazers, and competitors on Arctic kelp population dynamics in the future. In addition, the observed warming-induced reduction in the extent and thickness of sea ice in Svalbard (Pavlov et al. 2013) in combination with more intense and/or frequent storm events (Young et al. 2011) may increase internal bed dynamics through an increase in kelp detachment rates and ultimately strongly alter intra- and interspecific interactions in Arctic kelps. Besides wave-exposure, changes in temperature and nutrient concentration have the potential to interact with canopy effects on kelp recruitment (Kortsch et al. 2012; see Sect. 10.3.4 "Nutrient regime").

Present knowledge on the effects of kelp canopies and associated species on kelp performance and fitness comes predominantly from non-polar habitats. Most of these effects are kelp species-specific and/or site-specific and conclusions cannot be transferred directly to kelps from Arctic regions. As adult canopies are able to alter abiotic conditions for understory organisms, upcoming studies on intra- and interspecific interactions need to be conducted as manipulative field experiments with Arctic kelp species. Such studies will increase our understanding of how, and by how much, adult canopies and associated species alter kelp population dynamics in a present and future Arctic ocean.

\subsection{Future Scenarios \& Outlook}

The data collected from studies on the kelps of Kongsfjorden have increased substantially during the last two decades and this has greatly improved our understanding of kelp responses towards environmental variation in general, albeit mostly on the species level, while studies on the community level and on biotic stressors are still scarce. On the basis of the current knowledge, we can at least speculate with a higher degree of certainty on what the future kelp community of Kongsfjorden may look like. Proceeding Atlantification will most likely result in the Kongsfjorden seaweed flora and associated organisms to further resemble a more cold-temperate community, similar to those along the Norwegian west coast. An immigration of seaweed species is to be expected from Norwegian mainland coasts and taking advantage of Bear Island as a stepping-stone. For the kelp flora, this most likely entails the establishment of Laminaria hyperborea as another large macroalgal 
species. The modelling study by Müller et al. (2009a) allows some prospective view into the future biogeographical distribution patterns of North Atlantic kelps, based on current temperature tolerance ranges associated with biological traits such as growth, reproduction and recruitment, and predicted sea surface temperature distribution patterns. Based on that, the northward extension of current northern temperature limits can be taken for granted and may facilitate the spread of more and more temperate species migrating to the west coast of Svalbard. It is more difficult to predict to what extent increase in sea surface temperature in the North Atlantic will also set new southern distribution boundaries, as adaptive processes facilitating the adjustment of biological performance towards a changing temperature regime are difficult to implement in the models. However, recent large-scale kelp declines have already been reported from the North of Spain; the Southern distributional limit of a variety of cold temperate Atlantic kelps (Voerman et al. 2013). Thus, we can expect new seaweed arrivals to the Kongsfjorden area (Krause-Jensen and Duarte 2014); whether some species will have to depart from Kongsfjorden to more northern and eastern locations of Svalbard still needs to be evaluated.

While our predictions on changes in species community and distribution shifts are becoming more precise, present studies are still far from being conclusive as it comes to future trends in kelp productivity. Light availability as a driver of kelp productivity will undergo substantial alterations resultant from environmental change, but whether or not it will ultimately result in an overall change in underwater light availability has still to be resolved (see Pavlov et al., Chap. 5). Undoubtedly, ongoing Atlantification will reduce the extent and duration of sea ice cover, which potentially may result in an increase in light penetration into the water column (Krause-Jensen et al. 2012). On the other hand, increased atmospheric temperature and precipitation may increase snow melting, terrestrial run off and glacier calving, which both may result in an increase in the sediment load of Kongsfjorden waters, thus, reducing water transparency. Overall, these two scenarios may imply, that benthic organisms will experience an earlier start of the spring season, as light transmits earlier, deeper, and with higher irradiance into the water under the absence of ice and before the onset of the melting and run-off season (Krause-Jensen et al. 2012). Under run-off conditions light availability might be largely reduced, but the overall implications to kelp productivity remain to be evaluated.

Furthermore, the contribution of detached and degrading kelps to the flux of organic matter in Kongsfjorden is still understudied. Increased temperature may fuel overall microbial activity, but potentially also increase kelp detachment under intensified storms and wave action (Young et al. 2011). These two factors along with higher rates of primary productivity may result in an increased turnover of kelp debris. In this way carbon release to the system might be enhanced. Petrowski et al. (2016) show that even single kelp thalli may strongly affect diversity and structure of benthic soft bottom communities in Kongsfjorden when detached macroalgae are drifting on, or are being trapped in the sediment.

After almost 25 years of intense kelp research at Kongsfjorden, our understanding of physiological responses of kelps to a changing environment has advanced considerably. New analytical tools in molecular biology are becoming available for 
work on kelps as well, and a lot of new insights into stress perception and molecular control of acclimation processes are to be expected within the near future. These studies are of utmost importance in order to understand mechanisms and limitations of acclimation and adaptation for single species. Nevertheless, we need to accept and to be aware that the ecological significance of monospecific and/or monofactorial experiments is limited, given the enormous complexity of responses on the ecosystem level.

Still, the physiological studies on kelps of Kongsfjorden so far allow for some founded conclusions: In line with their generally wider distributional range, most kelp species found in the Arctic have broad tolerance ranges to most environmental variables. Regarding each of the kelp species in itself, and with the exception of the Arctic endemic Laminaria solidungula, most species will likely tolerate an increase in UV radiation, temperature and/or ocean acidification at the predicted ranges (see Sect. 10.3.3, 10.4.1, 10.4.2, 10.4.3, and 10.4.4). Still, as the early life-history stages are particularly susceptible, this has to be evaluated for the respective most sensitive stage (Sect. 10.4.5). In contrast, it is much more likely that a multitude of new ecological interactions will be formed (Sect. 10.4.6). Changing abiotic conditions will facilitate the arrival of organisms from lower latitudes and maybe also the introduction and establishment of non-indigenous species, all of which may alter the strength and direction of biotic interactions, including competition, epibiosis and grazing.

Conclusively, with respect to Kongsfjorden as a "hot spot" for environmental change, the following research priorities are proposed: More experiments addressing the interactive effects of abiotic and/or biotic stressors have to be conducted both on the physiological and ecological level. With the ecophysiological responses being extensively characterised already, molecular mechanisms and ecosystem consequences come into focus: we have to deepen our insights into regulatory mechanisms by large-scale gene expression and transcriptomic analyses on the one hand. On the other hand, we need to implement our findings in the context of species biology and ecology. Furthermore, population ecology and population genetics of kelps from the North Atlantic need to be revisited, checking for speciation processes or new connectivities facilitated by climate change. In this context, a timely examination and, if necessary, taxonomic revision of kelps populating the Arctic is also required.

The current, and certainly essential, debate on likely consequences of climate change, however, has led us to neglect another vital aspect in polar ecological science: Still our knowledge on the basic physiological adaptations allowing organisms to thrive in high polar environments is remarkably scarce. We need to make use of the latest analytical tools in order to improve our understanding of environmental signalling and the whole cellular machinery in order to reveal what makes kelps work under all constraints in high latitude environments. Further, there is an urgent need to implement the factor of seasonality in such studies. Knowledge of seaweed ecosystem functioning under Arctic winter conditions is near to nonexistent, but essential to understanding adaptive life strategies under polar conditions and adaptability in an era of climate change. Still, with its rich kelp flora on the 
doorstep and a superb infrastructure, Kongsfjorden and Ny-Ålesund represent the prime locations for addressing these scientific challenges.

Acknowledgements This review is largely based on the research conducted in the frame of the long-term project KOL 06 - Biology of Arctic benthic algae, performed at AWIPEV station, Ny-Ålesund. Authors are most grateful for the continuous support by the entire AWIPEV base team. Most of the studies presented would not have been possible without the AWI diving team.

\section{References}

Adey WH, Hayek LA (2011) Elucidating marine biogeography with macrophytes: quantitative analysis of the North Atlantic supports the thermogeographic model and demonstrates a distinct subarctic region in the Northwestern Atlantic. Northeast Nat 18:1-128

Agardh JG (1868) Bidrag till kännedomen om Spetsbergens alger. Tilläg till föregående afhandling. Kungliga Svenska Vetenskaps-Akademiens Handlingar. Nye Följd 7:28-49

Aguilera J, Karsten U, Lippert H, Vögele B, Philipp E, Hanelt D, Wiencke C (1999) Effects of solar radiation on growth, photosynthesis and respiration of marine macroalgae from the Arctic. Mar Ecol Prog Ser 191:109-119

Amsler CD, Fairhead VA (2006) Defensive and sensory chemical ecology of brown algae. Adv Bot Res 43:1-91

Axelsson L, Mercado JM, Figueroa FL (2000) Utilization of $\mathrm{HCO}_{3}{ }^{-}$at high $\mathrm{pH}$ by the brown macroalga Laminaria saccharina. Eur J Phycol 35:53-59

Barradas A, Alberto F, Engelen AH, Serrão EA (2011) Fast sporophyte replacement after removal suggests banks of latent microscopic stages of Laminaria ochroleuca (Phaeophyceae) in tide pools in northern Portugal. Cah Biol Mar 52:435-439

Bartsch I, Wiencke C, Laepple T (2012) Global seaweed biogeography under a changing climate: the prospected effects of temperature. In: Wiencke C, Bischof K (eds) Advances in seaweed biology. Novel insights into ecophysiology, ecology and utilization, Ecological studies, vol 219. Springer, Berlin/Heidelberg, pp 383-406

Bartsch I, Vogt J, Pehlke C, Hanelt D (2013) Prevailing sea surface temperatures inhibit summer reproduction of the kelp Laminaria digitata at Helgoland (North Sea). J Phycol 49:1061-1073

Bartsch I, Paar M, Fredriksen S, Schwanitz M, Daniel C, Hop H, Wiencke C (2016) Changes in kelp forest biomass and depth distribution in Kongsfjorden, Svalbard, between 1996-1998 and 2012-2014 reflect Arctic warming. Polar Biol 39:2021-2036

Bischof K, Rautenberger R (2012) Seaweed responses to environmental stress: reactive oxygen and antioxidative strategies. In: Wiencke C, Bischof K (eds) Advances in seaweed biology. Novel insights into ecophysiology, ecology and utilization, Ecological studies, vol 219. Springer, Berlin/Heidelberg, pp 109-132

Bischof K, Steinhoff FS (2012) Impacts of ozone depletion and solar UVB radiation on seaweeds. In: Wiencke C, Bischof K (eds) Advances in seaweed biology. Novel insights into ecophysiology, ecology and utilization, Ecological studies, vol 219. Springer, Berlin/Heidelberg, pp 433-448

Bischof K, Hanelt D, Tüg H, Karsten U, Brouwer PEM, Wiencke C (1998a) Acclimation of brown algal photosynthesis to ultraviolet radiation in Arctic coastal waters (Spitsbergen, Norway). Polar Biol 20:388-395

Bischof K, Hanelt D, Wiencke C (1998b) UV-radiation can affect depth-zonation of Antarctic macroalgae. Mar Biol 131:597-605

Bischof K, Hanelt D, Wiencke C (1999) Acclimation of maximal quantum yield of photosynthesis in the brown alga Alaria esculenta under high light and UV radiation. Plant Biol 1:435-444 
Bischof K, Peralta G, Kräbs G, van de Poll WH, Wiencke C, Perez-Llorens JL, Breeman AM (2002a) Effects of solar UVB radiation on canopy formation of natural Ulva communities from Southern Spain. J Exp Bot 53:2411-2421

Bischof K, Hanelt D, Aguilera J, Karsten U, Vögele B, Sawall T, Wiencke C (2002b) Seasonal variation in ecophysiological patterns in macroalgae from an Arctic fjord: I. Sensitivity of photosynthesis to ultraviolet radiation. Mar Biol 140:1097-1106

Bischof K, Gómez I, Molis M, Hanelt D, Karsten U, Lüder U, Roleda MY, Zacher K, Wiencke C (2006) Ultraviolet radiation shapes seaweed communities. Rev Environ Sci Biotechnol 5:141-166

Bischoff B, Wiencke C (1993) Temperature requirements for growth and survival of macroalgae from Disko Island (Greenland). Helgol Meeresunters 47:167-191

Bolton JJ, Lüning K (1982) Optimal-growth and maximal survival temperatures of atlantic Laminaria species (Phaeophyta) in culture. Mar Biol 66:89-94

Bouck GB (1965) Fine structure and organelle associations in brown algae. J Cell Biol 26:523-537

Brinkhuis BH, Chung IK (1986) The effects of copper on the fine structure of the kelp Laminaria saccharina (L.) Lamour. Mar Environ Res 19:205-223

Brodie J, Williamson CJ, Smale DA, Kamenos NA, Mieszkowska N, Santos R, Cunliffe M, Steinke M, Yesson C, Anderson KM, Asnaghi V, Brownlee C, Burdett HL, Burrows MT, Collins S, Donohue PJC, Harvey B, Foggo A, Noisette F, Nunes J, Ragazzola F, Raven JA, Schmidt DN, Suggett D, Teichberg M, Hall-Spencer JM (2014) The future of the northeast Atlantic benthic flora in a high $\mathrm{CO}_{2}$ world. Ecol Evol 4:2787-2798

Brown MB, Edwards MS, Kim KY (2014) Effects of climate change on the physiology of giant kelp, Macrocystis pyrifera, and grazing by purple urchin, Strongylocentrotus purpuratus. Algae 29:203-215

Busa W (1986) Mechanisms and consequences of pH-mediated cell regulation. Annu Rev Physiol 48:389-402

Carlsen BP, Johnsen G, Berge J, Kuklinski P (2007) Biodiversity patterns of macro-epifauna on different lamina parts of Laminaria digitata and Saccharina latissima collected during spring and summer 2004 in Kongsfjorden, Svalbard. Polar Biol 30:939-943

Chapman ARO, Craigie JS (1977) Seasonal growth in Laminaria longicruris: relation with dissolved inorganic nutrients and internal reserves of nitrogen. Mar Biol 40:197-205

Chapman ARO, Lindley JE (1980) Seasonal growth of Laminaria solidungula in the Canadian High Arctic in relation to irradiance and dissolved nutrients concentrations. Mar Biol 57:1-5

Christie H, Frederiksen S, Rinde E (1998) Regrowth of kelp and colonization of epiphyte and fauna community after kelp trawling at the coast of Norway. Hydrobiologia 375/376:49-58

Christie H, Norderhaug KM, Fredriksen S (2009) Macrophytes as habitat for fauna. Mar Ecol Prog Ser 396:221-233

Cock J, Sterck L, Rouze P, Scornet D, Allen A, Amoutzias G, Anthouard V, Artiguenave F, Aury JM, Badger J, Beszteri B, Billiau K, Bonnet E, Bothwell J, Bowler C, Boyen C, Brownlee C, Carrano C, Charrier B, Cho G, Coelho S, Collen J, Corre E, Da Silva C, Delage L, Delaroque N, Dittami S, Doulbeau S, Elias M, Farnham G, Gachon C, Gschloessl B, Heesch S, Jabbari K, Jubin C, Kawai H, Kimura K, Kloareg B, Kupper F, Lang D, Le Bail A, Leblanc C, Lerouge P, Lohr M, Lopez P, Martens C, Maumus F, Michel G, Miranda-Saavedra D, Morales J, Moreau H, Motomura T, Nagasato C, Napoli C, Nelson D, Nyvall-Collen P, Peters A, Pommier C, Potin P, Poulain J, Quesneville H, Read B, Rensing S, Ritter A, Rousvoal S, Samanta M, Samson G, Schroeder D, Segurens B, Strittmatter M, Tonon T, Tregear J, Valentin K, Von Dassow P, Yamagishi T, Van De Peer Y, Wincker P (2010) The Ectocarpus genome and the independent evolution of multicellularity in brown algae. Nature 465:617-621

Connell SD, Kroeker KJ, Fabricius KE, Kline DI, Russell BD (2013) The other ocean acidification problem: $\mathrm{CO}_{2}$ as a resource among competitors for ecosystem dominance. Philos Trans Roy Soc B-Biol Sci 368:20120442

Cottier FR, Nilsen F, Inall ME, Gerland S, Tverberg V, Svendsen H (2007) Wintertime warming of an Arctic shelf in response to large-scale atmospheric circulation. Geophys Res Lett 34:L10607 
Davison IR, Davison JO (1987) The effect of growth temperature on enzyme activities in the brown alga Laminaria saccharina. Br Phycol J 22:77-87

Davison IR, Pearson GA (1996) Stress tolerance in intertidal seaweeds. J Phycol 32:197-211

Davison I, Greene M, Podolak E (1991) Temperature acclimation of respiration and photosynthesis in the brown alga Laminaria saccharina. Mar Biol 110:449-454

Dayton PK (1985) Ecology of kelp communities. Annu Rev Ecol Syst 16:215-245

Deng Y, Yao J, Wang X, Guo H, Duan D (2012) Transcriptome sequencing and comparative analysis of Saccharina japonica (Laminariales, Phaeophyceae) under blue light induction. PLoS One 7:e39704

Dring MJ (1982) The biology of marine plants. Cambridge University Press, Cambridge

Duarte P, Weslawski JM, Hop H (this volume-b) Chapter 12: Outline of an Arctic fjord ecosystem model for Kongsfjorden-Krossfjorden, Svalbard. In: Hop H, Wiencke C (eds) The ecosystem of Kongsfjorden, Svalbard, Advances in polar ecology 2. Springer, Cham

Dunton KH (1985) Growth of dark-exposed Laminaria saccharina (L.) Lamour. and Laminaria solidungula J. Ag. (Laminariales, Phaeophyta) in the Alaskan Beaufort Sea. J Exp Mar Biol Ecol 94:181-189

Eckhardt S, Hermansen O, Grythe H, Fiebig M, Stebel K, Cassiani M, Baecklund A, Stohl A (2013) The influence of cruise ship emissions on air pollution in Svalbard - a harbinger of a more polluted Arctic? Atmos Chem Phys 13:8401-8409

Ehrenshaft M, Bilski P, Li MY, Chignell CF, Daub ME (1999) A highly conserved sequence is a novel gene involved in de novo vitamin $B_{6}$ biosynthesis. Proc Nat Acad Sci 96:9374-9378

Engardt M, Holmén K (1996) Towards deducing regional sources and sinks from atmospheric $\mathrm{CO}_{2}$ measurements at Spitsbergen. Phys Chem Earth 21:523-528

Engardt M, Holmén K, Heintzenberg J (1996) Short-term variations in atmospheric $\mathrm{CO}_{2}$ at Ny-Ålesund, Spitsbergen, during spring and summer. Tellus 48B:33-43

Falkenberg LJ, Connell SD, Russell BD (2014) Herbivory mediates the expansion of an algal habitat under nutrient and $\mathrm{CO}_{2}$ enrichment. Mar Ecol Prog Ser 497:87-92

Feehan C, Scheibling RE, Lauzon-Guay JS (2012) Aggregative feeding behaviour in sea urchins leads to destructive grazing in a Nova Scotia kelp bed. Mar Ecol Prog Ser 444:69-83

Fernández PA, Hurd CL, Roleda MY (2014) Bicarbonate uptake via an anion exchange protein is the main mechanism of inorganic carbon acquisition by the giant kelp Macrocystis pyrifera (Laminariales, Phaeophyceae) under variable pH. J Phycol 50:998-1008

Fernández PA, Roleda MY, Hurd CL (2015) Effects of ocean acidification on the photosynthetic performance, carbonic anhydrase activity and growth of the giant kelp Macrocystis pyrifera. Photosynth Res 124:293-304

Flores-Moya A, Fernandez JA (1998) The role of external carbonic anhydrase in the photosynthetic use of inorganic carbon in the deep-water alga Phyllariopsis purpurascens (Laminariales, Phaeophyta). Planta 207:115-119

Foslie MH (1884) Ueber die Laminarien Norwegens. Christiania videnskapelige selskaps forhandlinger no $14,112 \mathrm{pp}$

Franklin LA, Forster RM (1997) The changing irradiance environment: consequences for marine macrophyte physiology, productivity and ecology. Eur J Phycol 32:207-232

Fredersdorf J, Müller R, Becker S, Wiencke C, Bischof K (2009) Interactive effects of radiation, temperature and salinity on different life history stages of the Arctic kelp Alaria esculenta (Phaeophyceae). Oecologia 160:483-492

Fredriksen S, Kile MR (2012) The algal vegetation in the outer part of Isfjorden, Spitsbergen: revisiting Per Svendsen's sites 50 years later. Polar Res 31. https://doi.org/10.3402/polar. v31i0.17538

Fredriksen S, Bartsch I, Wiencke C (2014) New additions to the benthic marine flora of Kongsfjorden, western Svalbard, and comparison between 1996/1998 and 2012/2013. Bot Mar 57:203-216

Fredriksen S, Karsten U, Bartsch I, Woelfel J, Koblowsky M, Schumann R, Moy SR, Steneck RS, Wiktor J, Hop H, Wiencke C (this volume) Chapter 9: Biodiversity of benthic macro- and 
microalgae from Svalbard with special focus on Kongsfjorden. In: Hop H, Wiencke C (eds) The ecosystem of Kongsfjorden, Svalbard, Advances in polar ecology 2. Springer, Cham

Friedrich MW (2012) Bacterial communities on macroalgae. In: Wiencke C, Bischof K (eds) Advances in seaweed biology. Novel insights into ecophysiology, ecology and utilization, Ecological studies, vol 219. Springer, Berlin/Heidelberg, pp 189-201

Gagnon P, Himmelman JH, Johnson LE (2003) Algal colonization in urchin barrens: defense by association during recruitment of the brown alga Agarum cribrosum. J Exp Mar Biol Ecol 290:179-196

Gaitan-Espitia JD, Hancock JR, Padilla-Gamino JL, Rivest EB, Blanchette CA, Reed DC, Hofmann GE (2014) Interactive effects of elevated temperature and $p \mathrm{CO}_{2}$ on early life-history stages of the giant kelp Macrocystis pyrifera. J Exp Mar Biol Ecol 457:51-58

Gao K, Xu J (2010) Ecological and physiological responses of macroalgae to solar and UV radiation. In: Israel A, Einav R, Seckbach J (eds) Seaweeds and their role in globally changing environments. Springer, Dordrecht, pp 183-198

García-Gómez C, Parages ML, Jiménez C, Palma A, Mata MT, Segovia M (2012) Cell survival after UV radiation stress in the unicellular chlorophyte Dunaliella tertiolecta is mediated by DNA repair and MAPK phosphorylation. J Exp Bot 63:5259-5274

Gerard VA (1997) Environmental stress during early development of kelp sporophytes (Laminaria saccharina): how long do effects persist? J Appl Phycol 9:5-9

Gévaert F, Créach A, Davoult D, Migné A, Levavasseur G, Arzel P, Holl AC, Lemoine Y (2003) Laminaria saccharina photosynthesis measured in situ: photoinhibition and xanthophyll cycle during a tidal cycle. Mar Ecol Prog Ser 247:43-50

Gordillo FJL, Dring MJ, Savidge G (2001a) Nitrate and phosphate uptake characteristics of three brown algae cultured at low salinity. Mar Ecol Prog Ser 234:111-118

Gordillo FJL, Niell FX, Figueroa FL (2001b) Non-photosynthetic enhancement of growth by high $\mathrm{CO}_{2}$ level in the nitrophilic seaweed Ulva rigida C. Agardh (Chlorophyta). Planta 213:64-70

Gordillo FJL, Aguilera J, Jiménez C (2006) The response of nutrient assimilation and biochemical composition of Arctic seaweeds to a nutrient input in summer. J Exp Bot 57:2661-2671

Gordillo FJL, Aguilera J, Wiencke C, Jiménez C (2015) Ocean acidification modulates the response of two Arctic kelps to ultraviolet radiation. J Plant Physiol 173:41-50

Graham MH (1997) Factors determining the upper limit of giant kelp, Macrocystis pyrifera Agardh, along the Monterey Peninsula, central California, USA. J Exp Mar Biol Ecol 218:127-149

Graham MH, Kinlan BP, Druhel LD, Garske LE, Banks S (2007) Deep-water refugia as potential hotspots of tropical marine diversity and productivity. Proc Nat Acad Sci 104:16576-16580

Gruber A, Roleda M, Bartsch I, Hanelt D, Wiencke C (2011) Sporogenesis under ultraviolet radiation in Laminaria digitata (Phaeophyceae) reveals protection of photosensitive meiospores within soral tissue: physiological and anatomical evidence. J Phycol 47:603-614

Halm H, Lüder UH, Wiencke C (2011) Induction of phlorotannins through mechanical wounding and radiation conditions in the brown macroalga Laminaria hyperborea. Eur J Phycol 46:16-26

Hanelt D (1998) Capability of dynamic photoinhibition in Arctic macroalgae is related to their depth distribution. Mar Biol 131:361-369

Hanelt D, Roleda MY (2009) Acclimation to UVB radiation may induce a reduction in photoinhibitory stress on some Caribbean marine macrophytes. Aquat Bot 91:6-12

Hanelt D, Wiencke C, Karsten U, Nultsch W (1997) Photoinhibition and recovery after high light stress in different developmental and life-history stages of Laminaria saccharina (Phaeophyta). J Phycol 33:387-395

Hanelt D, Tüg H, Bischof K, Gross C, Lippert H, Sawall T, Wiencke C (2001) Light regime in an Arctic fjord: a study related to stratospheric ozone depletion as a basis for determination of UV effects on algal growth. Mar Biol 138:649-658

Hansen JR, Jenneborg LH (1996) Benthic marine algae and cyanobacteria. In: Elvebakk A, Presterud P (eds) A catalogue of Svalbard plants, fungi, algae and cyanobacteria, vol 198. Norsk Polarinstitutts Skrifter, Oslo, pp 361-374 
Harley CDG, Anderson KM, Demes KW, Jorve JP, Kordas RL, Coyle TA, Graham MH (2012) Effects of climate change on global seaweed communities. J Phycol 48:1064-1078

Harris NRP, Kyr E, Staehelin J, Brunner D, Andersen SB, Godin-Beekmann S, Dhomse S, Hadjinicolaou P, Hansen G, Isaksen I, Jrrar A, Karpetchko A, Kivi R, Knudsen B, Krizan P, Lastovicka J, Maeder J, Orsolini Y, Pyle JA, Rex M, Vanicek K, Weber M, Wohltmann I, Zanis P, Zerefos C (2008) Ozone trends at northern mid- and high latitudes - a European perspective. Ann Geophys 26:1207-1220

Hegseth EN, Tverberg V (2013) Effect of Atlantic water inflow on timing of the phytoplankton spring bloom in a high Arctic fjord (Kongsfjorden, Svalbard). J Mar Syst 113-114:94-105

Heinrich S, Frickenhaus S, Glöckner G, Valentin K (2012a) A comprehensive cDNA library of light- and temperature-stressed Saccharina latissima (Phaeophyceae). Eur J Phycol 47:83-94

Heinrich S, Valentin KU, Frickenhaus S, John U, Wiencke C (2012b) Transcriptomic analysis of acclimation to temperature and light stress in Saccharina latissima (Phaeophyceae). PLoS One 7:e44342

Heinrich S, Valentin K, Frickenhaus S, Wiencke C (2015) Temperature and light interactively modulate gene expression in Saccharina latissima (Phaeophyceae). J Phycol 51:93-108

Heinrich S, Valentin K, Frickenhaus S, Wiencke C (2016) Origin matters - comparative transcriptomics in Saccharina latissima (Phaeophyceae). J Exp Mar Biol Ecol 476:22-30

Henley WJ, Dunton KH (1997) Effects of nitrogen supply and continuous darkness on growth and photosynthesis of the Arctic kelp Laminaria solidungula. Limnol Oceanogr 42:209-216

Hernandez I, Corzo A, Gordillo FJ, Robles MD, Saez E, Fernandez JA, Niell FX (1993) Seasonal cycle of the gametophytic form of Porphyra umbilicalis: nitrogen and carbon. Mar Ecol Prog Ser 99:301-311

Hodal H, Falk-Petersen S, Hop H, Kristiansen S, Reigstad M (2011) Spring bloom dynamics in Kongsfjorden, Svalbard: nutrients, phytoplankton, protozoans and primary production. Polar Biol 35:191-203

Hofmann G, Place S (2007) Genomics-enabled research in marine ecology: challenges, risks and pay-offs. Mar Ecol Prog Ser 332:249-255

Holzinger A, Lütz C (2006) Algae and UV irradiation: effects on ultrastructure and related metabolic functions. Micron 37:190-207

Holzinger A, Di Piazza L, Lütz C, Roleda MY (2011) Sporogenic and vegetative tissues of Saccharina latissima (Laminariales, Phaeophyceae) exhibit distinctive sensitivity to experimentally enhanced ultraviolet radiation: photosynthetically active radiation ratio. Phycol Res 59:221-235

Hop H, Pearson T, Hegseth EN, Kovacs KM, Wiencke C, Kwasniewski S, Eiane K, Mehlum F, Gulliksen B, Wlodarska-Kowalczuk M, Lydersen C, Weslawski JM, Cochrane S, Gabrielsen GW, Leakey RJG, Lønne OJ, Zajaczkowski M, Falk-Petersen S, Kendall M, Wängberg S-Å, Bischof K, Voronkov AY, Kovaltchouk NA, Wiktor J, Poltermann M, di Prisco G, Papucci C, Gerland S (2002) The marine ecosystem of Kongsfjorden, Svalbard. Polar Res 21:167-208

Hop H, Wiencke C, Vögele B, Kovaltchouk N (2012) Species composition, zonation, and biomass of marine benthic macroalgae in Kongsfjorden, Svalbard. Bot Mar 55:399-414

Hop H, Kovaltchouk NA, Wiencke C (2016) Distribution of macroalgae in Kongsfjorden. Polar Biol 39:2037-2051

Hulme M, Jenkins GJ, Lu X, Turnpenny JR, Mitchell TD, Jones RG, Lowe J, Murphy JM, Hassell D, Boorman P, McDonald R, Hill S (2002) Climate change scenarios for the United Kingdom: the UKCIP02 scientific report. Tyndall Centre for Climate Change Research, School of Environmental Sciences, University of East Anglia, Norwich, 120 pp

Hurd CL, Harrison PJ, Bischof K, Lobban CS (2014) Seaweed ecology and Physiology, 2nd edn. Cambridge University Press, Cambridge, p 551

Husa V, Steen H, Sjøtun K (2014) Historical changes in macroalgal communities in Hardangerfjord (Norway). Mar Biol Res 10:226-240 
Iken K (2012) Grazers on benthic seaweeds. In: Wiencke C, Bischof K (eds) Advances in seaweed biology. Novel insights into ecophysiology, ecology and utilization, Ecological studies, vol 219. Springer, Berlin/Heidelberg, pp 157-175

Iñiguez C, Carmona R, Lorenzo MR, Niell FX, Wiencke C, Gordillo FJL (2016) Increased $p \mathrm{CO}_{2}$ modifies the carbon balance and the photosynthetic yield of two common Arctic brown seaweeds: Desmarestia aculeata and Alaria esculenta. Polar Biol 39:1979-1991

IPCC (2013) Climate change 2013: the physical science basis. Contribution of working group I to the fifth assessment report of the intergovernmental panel on climate change $1535 \mathrm{pp}$

Jamers A, Blust R, De Coen W (2009) Omics in algae: paving the way for a systems biological understanding of algal stress phenomena? Aquat Toxicol 92:114-121

Jiménez C, Berl T, Rivard CJ, Edelstein CL, Capasso JM (2004) Phosphorylation of MAP kinaselike proteins mediate the response of the halotolerant alga Dunaliella viridis to hypertonic shock. Biochim Biophys Acta 1644:61-69

Jiménez C, Cossío BR, Rivard CJ, Berl T, Edelstein CL, Capasso JM (2007) Cell division in the unicellular microalga Dunaliella viridis depends on phosphorylation of extracellular signalregulated kinases (ERKs). J Exp Bot 58:1001-1011

Jokiel PL, Jury CP, Rodgers KS (2014) Coral-algae metabolism and diurnal changes in the $\mathrm{CO}_{2}$ carbonate system of bulk seawater. Peer J 2:e378

Jueterbock A, Tyberghein L, Verbruggen H, Coyer JA, Olsen JL, Hoarau G (2013) Climate change impact on seaweed meadow distribution in the North Atlantic rocky intertidal. Ecol Evol $12: 1356-1373$

Jury CP, Thomas FIM, Atkinson MJ, Toonen RJ (2013) Buffer capacity, ecosystem feedbacks, and seawater chemistry under global change. Water 5:1303-1325

Karleskint G, Turner R, Small J (2010) Introduction to marine biology. Brooks/Cole, Belmont

Karsten U, Bischof K, Wiencke C (2001) Photosynthetic performance of Arctic macroalgae after transplantation from deep to shallow waters followed by exposure to natural solar radiation. Oecologia 127:11-20

Klenell M, Snoeijs P, Pedersen M (2004) Active carbon uptake in Laminaria digitata and L. saccharina (Phaeophyta) is driven by a proton pump in the plasma membrane. Hydrobiologia 514:41-53

Konotchick T, Dupont CL, Valas RE, Badger JH, Allen AE (2013) Transcriptomic analysis of metabolic function in the giant kelp, Macrocystis pyrifera, across depth and season. New Phytol 198:398-407

Korb RE, Gerard VA (2000a) Nitrogen assimilation characteristics of polar seaweeds from differing nutrient environment. Mar Ecol Prog Ser 198:83-92

Korb RE, Gerard VA (2000b) Effects of concurrent low temperature and low nitrogen supply on polar and temperate waters. Mar Ecol Prog Ser 198:73-82

Kortsch S, Primicerio R, Beuchel F, Renaud PE, Rodrigues J, Lønne OJ, Gulliksen B (2012) Climate-driven regime shifts in Arctic marine benthos. Proc Nat Acad Sci 109:14052-14057

Krause-Jensen D, Duarte C (2014) Expansion of vegetated coastal ecosystems in the future Arctic. Front Mar Sci 1:77. https://doi.org/10.3389/fmars.2014.00077

Krause-Jensen D, Marbà N, Olesen B, Sejr MK, Christensen PB, Rodrigues J, Renaud PE, Balsby TJS, Rysgaard S (2012) Seasonal sea ice cover as principal driver of spatial and temporal variation in depth extension and annual production of kelp in Greenland. Glob Change Biol 10:2981-2994

Krauss G (2008) Biochemistry of signal transduction and regulation. Wiley-VCH Verlag GMBH and Co. KGaA, Weinheim, $626 \mathrm{pp}$

Lampert WJ, Levin PS, Berman J (1992) Changes in the structure of a New England (USA) kelp bed: the effects of an introduced species? Mar Ecol Prog Ser 88:303-307

Lapointe BE (2004) Anthropogenic nutrient enrichment of seagrass and coral reef communities in the lower Florida Keys: discrimination of local versus regional nitrogen sources. J Exp Mar Biol Ecol 308:23-58 
Lippert H, Iken K, Rachor E, Wiencke C (2001) Macrofauna associated with macroalgae in the Kongsfjord (Spitzbergen). Polar Biol 24:512-522

Longtin CM, Saunders GW (2015) On the utility of mucilage ducts as a taxonomic character in Laminaria and Saccharina (Phaeophyceae) - the conundrum of S. groenlandica. Phycologia 54:440-450

Longtin CM, Saunders GW (2016) The relative contribution of Saccharina nigripes (Phaeophyceae) to the Bay of Fundy Laminariaceae: spatial and temporal variability. Mar Ecol Prog Ser 543:153-162

Lüder UH, Clayton MN (2004) Induction of phlorotannins in the brown macroalga Ecklonia radiata (Laminariales, Phaeophyta) in response to simulated herbivory-the first microscopic study. Planta 218:928-937

Lund L (2014) Morphological diversity in Laminaria digitata. MSc thesis in Marine Biology, NTNU, Trondheim, $65 \mathrm{pp}$

Lüning K (1990) Seaweeds - their environment, biogeography and ecophysiology. John Wiley \& Sons Inc, New York. 527 pp

Lüning K (1991) Circannual growth rhythm in a brown alga, Pterygophora californica. Bot Act 104:157-162

Lütz C, Di Piazza L, Fredersdorf J, Bischof K (2016) The effect of ultraviolet radiation on cellular ultrastructure and photosystem II quantum yield of Alaria esculenta (L.) Greville from Spitsbergen (Norway). Polar Biol 39:1957-1966

Machalek K, Davison I, Falkowski P (1996) Thermal acclimation and photoacclimation of photosynthesis in the brown alga Laminaria saccharina. Plant Cell Environ 19:1005-1016

Mackerness SH, Jordan BR, Thomas B (1999) Reactive oxygen species in the regulation of photosynthetic genes by ultraviolet-B radiation (UVB: $280-320 \mathrm{~nm}$ ) in green and etiolated buds of pea (Pisum sativum L.). J Photochem Photobiol B Biol 48:180-188

Manney GL, Santee ML, Rex M, Livesey NJ, Pitts MC, Veefkind P, Nash ER, Wohltmann I, Lehmann R, Froidevaux L, Poole LR, Schoeberl MR, Haffner DP, Davies J, Dorokhov V, Gernandt H, Johnson B, Kivi R, Kyrö E, Larsen N, Levelt PF, Makshtas A, McElroy CT, Nakajima H, Parrondo MC, Tarasick DW, von der Gathen P, Walker KA, Zinoviev NS (2011) Unprecedented Arctic ozone loss in 2011. Nature 478:469-475

McDevit DC, Saunders GW (2010) A DNA barcode examination of the Laminariaceae (Phaeophyceae) in Canada reveals novel biogeographical and evolutionary insights. Phycologia 49:235-248

McKenzie R, Smale D, Kotkamp M (2004) Relationship between UVB and erythemally weighted radiation. Photochem Photobiol Sci 3:252-256

McNeil BI, Matear RJ (2008) Southern Ocean acidification: a tipping point at 450-ppm atmospheric $\mathrm{CO}_{2}$. Proc Nat Acad Sci 105:18860-18864

Mercado JM, Andria JR, Perez-Llorens JL, Vergara JJ, Axelsson L (2006) Evidence for a plasmalemma-based $\mathrm{CO}_{2}$ concentrating mechanism in Laminaria saccharina. Photosynth Res $88: 259-268$

Michler T, Aguilera J, Hanelt D, Bischof K, Wiencke C (2002) Long-term effects of ultraviolet radiation on growth and photosynthetic performance of polar and cold-temperate marcoalgae. Mar Biol 140:1117-1127

Moy SR (2015) Littoral and sublittoral macroalgal vegetation from 8 sites around Svalbard. MSc thesis in Marine Biology, University of Oslo, Oslo, $120 \mathrm{pp}$

Moy FE, Christie H (2012) Large-scale shift from sugar kelp (Saccharina latissima) to ephemeral algae along the south and west coast of Norway. Mar Biol Res 8:309-321

Müller R, Wiencke C, Bischof K (2008) Interactive effects of UV radiation and temperature on microstages of Laminariales (Phaeophyceae) from the Arctic and North Sea. Clim Res 37:203-213

Müller R, Laepple T, Bartsch I, Wiencke C (2009a) Impact of oceanic warming on the distribution of seaweeds in polar and cold-temperate waters. Bot Mar 52:617-638 
Müller R, Wiencke C, Bischof K, Krock B (2009b) Zoospores of three Arctic Laminariales under different UV radiation and temperature conditions: exceptional spectral absorbance properties and lack of phlorotannin induction. Photochem Photobiol 85:970-977

Norderhaug KM, Christie H (2011) Secondary production in a Laminaria hyperborea kelp forest and variation according to wave exposure. Estuar Coast Shelf Sci 95:135-144

Nordli Ø, Przybylak R, Ogilvie AEJ, Isaksen K (2014) Long-term temperature trends and variability on Spitsbergen: the extended Svalbard Airport temperature series, 1898-2012. Polar Res 33:21349

Olischläger M, Wiencke C (2013) Seasonal fertility and combined effects of temperature and UV-radiation on Alaria esculenta and Laminaria digitata (Phaeophyceae) from Spitsbergen. Polar Biol 36:1019-1029

Olischläger M, Bartsch I, Gutow L, Wiencke C (2012) Effects of ocean acidification on different life-cycle stages of the kelp Laminaria hyperborea (Phaeophyceae). Bot Mar 55:511-525

Parages ML (2012) Role of mitogen activated protein kinases (MAPKs) cascades in environmental stress signal transduction in intertidal and Arctic macrophytes. PhD dissertation, University of Málaga

Parages ML, Capasso JM, Meco V, Jiménez C (2012) A novel method for phosphoprotein extraction from macroalgae. Bot Mar 55:261-267

Parages ML, Heinrich S, Wiencke C, Jiménez C (2013) Rapid phosphorylation of MAP kinaselike proteins in two species of Arctic kelps in response to temperature and UV radiation stress. Environ Exp Bot 91:30-37

Parages ML, Capasso JM, Niell FX, Jiménez C (2014a) Environmental stress response by cyclic phosphorylation of MAP kinase-like proteins in intertidal macrophytes. J Plant Physiol 171:276-284

Parages ML, Figueroa FL, Conde-Alvarez RM, Jiménez C (2014b) Phosphorylation of MAPKlike proteins in three intertidal macroalgae under stress conditions. Aquat Biol 22:213-226

Pavlov AK, Tverberg V, Ivanov BV, Nilsen F, Falk-Petersen S, Granskog MA (2013) Warming of Atlantic Water in two west Spitsbergen fjords over the last century (1912-2009). Polar Res 32:11206

Pavlov A, Leu E, Bartsch I, Karsten U, Berge J, Cottier F, Schulz K, Johnsen G, Hanelt D, Granskog MA, Hudson S, Darecki M, Sagan S, Kowalczuk P, Bischof K, Pedersen P, Gallet J-C, Gerland $\mathrm{S}$ (this volume-c) Chapter 5: Underwater light in Kongsfjorden and its ecological implications. In: Hop H, Wiencke C (eds) Ecosystem Kongsfjorden, Svalbard: arctic marine environment, ecosystem structure and function, physiological adaptations, effects of climate and anthropogenic changes, Long-term trends and models, Advances in polar ecology 2. Springer, Cham

Pedersen PM (2011) Grønlands havalger. Epsilon, Copenhagen, 208 pp

Pedersen MF, Nejrup LB, Frederiksen S, Christie H, Norderhaug KM (2012) Effects of wave exposure on population structure, demography, biomass and productivity of the kelp Laminaria hyperborea. Mar Ecol Prog Ser 451:45-60

Petrowski S, Molis M, Bender A, Buschbaum C (2016) Disturbance effects of kelp thalli on structure and diversity of a coastal Arctic marine soft-bottom assemblage. Polar Biol 39:2131-2140

Piquet AMT, van de Poll WH, Visser RJW, Wiencke C, Bolhuis H, Buma AGJ (2014) Springtime phytoplankton dynamics in Arctic Krossfjorden and Kongsfjorden (Spitsbergen) as a function of glacier proximity. Biogeoscience 11:2263-2279

Piquet AMT, Maat DS, Confurius-Guns V, Sintes E, Herndl GJ, Wiencke C, Buma AGJ, Bolhuis $\mathrm{H}$ (2015) Springtime dynamics, productivity and activity of prokaryotes in two Arctic fjords. Polar Biol 39:1749-1763

Polo LK, de L, Felix MR, Kreusch M, Pereira DT, Costa GB, Simioni C, Ouriques LC, Chow F, Ramlov F, Maraschin M, Bouzon ZL, Schmidt EC (2014) Photoacclimation responses of the brown macroalga Sargassum cymosum to the combined influence of UV radiation and salinity: cytochemical and ultrastructural organization and photosynthetic performance. Photochem Photobiol 90:560-573 
Potin P (2012) Intimate associations between epiphytes, endophytes, and parasites of seaweeds. In: Wiencke C, Bischof K (eds) Advances in seaweed biology. Novel insights into ecophysiology, ecology and utilization, Ecological studies, vol 219. Springer, Berlin/Heidelberg, pp 203-234

Rautenberger R, Fernández PA, Strittmatter M, Heesch S, Cornwall CE, Hurd CL, Roleda MY (2015) Saturating light and not increased carbon dioxide under ocean acidification drives photosynthesis and growth in Ulva rigida (Chlorophyta). Ecol Evol 5:874-888

Raven JA, Caldeira K, Elderfield $\mathrm{H}$ et al. (2005) Ocean acidification due to increasing atmospheric carbon dioxide. The Royal Society. The Clyvedon Press Ltd, Cardiff, 68 pp

Raybaud V, Beaugrand G, Goberville E, Delebecq G, Destombe C, Valero M, Davoult D, Morin P, Gevaert F (2013) Decline in kelp in west Europe and climate. Plos One 8:e66044

Rayko E, Maumus F, Maheswari U, Jabbari K, Bowler C (2010) Transcription factor families inferred from genome sequences of photosynthetic stramenopiles. New Phytol 188:52-66

Rokkan Iversen KR, Seuthe L (2011) Seasonal microbial processes in a high-latitude fjord (Kongsfjorden, Svalbard): I. Heterotrophic bacteria, picoplankton and nanoflagellates. Polar Biol 34:731-749

Roleda MY (2009) Photosynthetic response of Arctic kelp zoospores exposed to radiation and thermal stress. Photochem Photobiol Sci 8:1302-1312

Roleda MY (2016) Stress physiology and reproductive phenology of Arctic endemic kelp Laminaria solidungula. J Agardh. Polar Biol 39:1967-1977

Roleda MY, Hurd CL (2012) Seaweed responses to ocean acidification. In: Wiencke C, Bischof K (eds) Advances in seaweed biology. Novel insights into ecophysiology, ecology and utilization, Ecological studies, vol 219. Springer, Berlin/Heidelberg, pp 407-431

Roleda MY, Hanelt D, Kräbs G, Wiencke C (2004) Morphology, growth, photosynthesis and pigments in Laminaria ochroleuca (Laminariales, Phaeophyta) under UV radiation. Phycologia 43:603-613

Roleda MY, Hanelt D, Wiencke C (2005a) Growth kinetics related to physiological parameters in young Saccorhiza dermatodea and Alaria esculenta sporophytes exposed to UV radiation. Polar Biol 28:539-549

Roleda MY, Wiencke C, Hanelt D, van de Poll WH, Gruber A (2005b) Sensitivity of Laminariales zoospores from Helgoland (North Sea) to ultraviolet and photosynthetically active radiation: implications for depth distribution and seasonal reproduction. Plant Cell Environ 28:466-479

Roleda MY, Wiencke C, Lüder UH (2006a) Impact of ultraviolet radiation on cell structure, UV-absorbing compounds, photosynthesis, DNA damage and germination in zoospores of Arctic Saccorhiza dermatodea. J Exp Bot 57:3847-3847

Roleda MY, Wiencke C, Hanelt D (2006b) Thallus morphology and optical characteristics affect growth and DNA damage by UV radiation in juvenile Arctic Laminaria sporophytes. Planta 223:407-417

Roleda MY, Hanelt D, Wiencke C (2006c) Growth and DNA damage in young Laminaria sporophytes exposed to ultraviolet radiation: implication for depth zonation of kelps on Helgoland (North Sea). Mar Biol 148:1201-1211

Roleda MY, Hanelt D, Wiencke C (2006d) Exposure to ultraviolet radiation delays photosynthetic recovery in Arctic kelp zoospores. Photosynth Res 88:311-322

Roleda MY, Wiencke C, Hanelt D, Bischof K (2007) Sensitivity of the early life stages of macroalgae to ultraviolet radiation. Photochem Photobiol 83:851-862

Roleda MY, Dethleff D, Wiencke C (2008) Transient sediment load on blades of Arctic Saccharina latissima can mitigate UV radiation effect on photosynthesis. Polar Biol 31:765-769

Roleda MY, Lüder U, Wiencke C (2010) UV-susceptibility of zoospores of the brown macroalga Laminaria digitata from Spitsbergen. Polar Biol 33:577-588

Roleda MY, Morris JN, McGraw CM, Hurd CL (2012a) Ocean acidification and seaweed reproduction: increased $\mathrm{CO}_{2}$ ammeliorates the negative effect of lowered $\mathrm{pH}$ on meiospore germination in the giant kelp Macrocystis pyrifera (Laminariales, Phaeophyceae). Global Change Biol $18: 854-864$ 
Roleda MY, Boyd PW, Hurd CL (2012b) Before ocean acidification: calcifier chemistry lessons. J Phycol 48:840-843

Roleda MY, Cornwall CE, Feng YY, McGraw CM, Smith AM, Hurd CL (2015) Effect of ocean acidification and $\mathrm{pH}$ fluctuations on the growth and development of coralline algal recruits, and an associated benthic algal assemblages. PLos One:e0140394. https://doi.org/10.1371/journal. pone. 0140394

Ronowicz M, Wlodarska-Kowalczuk M, Kuklinski P (2008) Factors influencing hydroids (Cnidaria: Hydrozoa) biodiversity and distribution in Arctic kelp forest. J Mar Biol Ass UK 88:1567-1575

Ronowicz M, Legezynska J, Kuklinski P, Wlodarska-Kowalczuk M (2013) Kelp forest as a habitat for mobile epifauna: case study of Caprella septentrionalis Kröyer, 1838 (Amphipoda, Caprellidae) in an Arctic glacial fjord. Polar Res 32:1-6

Rosenvinge LK (1893) Grønlands havalger. Medd Grønland 3:763-981

Royal Society (2005) Ocean acidification due to increasing atmospheric carbon dioxide, Policy document 12/05 Royal Society, London. The Clyvedon Press Ltd, Cardiff

Rózycki O, Gruszczynski M (1986) Macrofana associated with laminarians in the coastal waters of West Spitsbergen. Polish Polar Res 7:337-351

Rueness J (1977) Norsk algeflora. Universitetsforlaget Oslo, Bergen, Tromsø. 266 pp

Saier B, Chapman AS (2004) Crusts of the alien bryozoan Membranipora membranacea can negatively impact spore output from native kelps (Laminaria longicruris). Bot Mar 47:265-271

Schaffelke B, Lüning K (1994) A circannual rhythm controls seasonal growth in the kelps Laminaria hyperborea and $L$. digitata from Helgoland (North Sea). Eur J Phycol 29:49-56

Schiffgens-Gruber A, Lütz C (1992) Ultrastructure of mesophyll cell chloroplasts of spruce needles exposed to $\mathrm{O}_{3}, \mathrm{SO}_{2}$ and $\mathrm{NO}_{2}$ alone and in combination. Environ Exp Bot 32:243-254

Schmitz K, Kühn R (1982) Fine structure, distribution and frequency of plasmodesmata and pits in the cortex of Laminaria hyperborea and L. saccharina. Planta 154:385-392

Schoenwaelder MEA (2002) The occurrence and cellular significance of physodes in brown algae. Phycologia 41:125-139

Schoenwaelder MEA, Clayton MN (1998) Secretion of phenolic substances into the zygote wall and cell plate in embryos of Hormosira and Acrocarpia (Fucales, Phaeophyceae). J Phycol 34:969-980

Schreiber U, Bilger W, Neubauer C (1994) Chlorophyll fluorescence as a non-intrusive indicator for rapid assessment of in vivo photosynthesis. Ecol Stud 100:49-70

Sivertsen K (1997) Geographic and environmental factors affecting the distribution of kelp beds and barren grounds and changes in biota associated with kelp reduction at sites along the Norwegian coast. Can J Aquat Sci 54:2872-2887

Sjøtun K, Christie H, Fosså JH (2006) The combined effect of canopy shading and sea urchin grazing on recruitment in kelp forest (Laminaria hyperborea). Mar Biol Res 2:24-32

Steinhoff F, Wiencke C, Bischof K (2008) Effects of ultraviolet radiation and temperature on the ultrastructure of zoospores of the brown macroalga Laminaria hyperborea. Plant Biol 10:388-397

Steinhoff FS, Graeve M, Wiencke C, Wulff A, Bischof K (2011a) Lipid content and fatty acid consumption in zoospores/developing gametophytes of Saccharina latissima (Laminariales, Phaeophyceae) as potential precursors for secondary metabolites as phlorotannins. Polar Biol 34:1011-1018

Steinhoff FS, Wiencke C, Wuttke S, Bischof K (2011b) Effects of water temperatures, UV radiation and low versus high PAR on phlorotannin content and germination in zoospores of Saccorhiza dermatodea (Tilopteridales, Phaeophyceae). Phycologia 50:256-263

Steneck RS, Graham MH, Bourque BJ, Corbett D, Erlandson JM, Estes JA, Tegner MJ (2002) Kelp forest ecosystems: biodiversity, stability, resilience and future. Environ Conserv 29:436-459

Sun J, Wang L, Wu SX, Wang XM, Xiao JF, Chi S, Liu C, Ren LF, Zhao YH, Liu T, Yu J (2014) Transcriptome-wide evolutionary analysis on essential brown algae (Phaeophyceae) in China. Acta Oceanol Sin 33:13-19 
Surif MB, Raven JA (1989) Exogenous inorganic carbon sources for photosynthesis in seawater by members of the Fucales and the Laminariales (Phaeophyta): ecological and taxonomic implications. Oecologia 78:97-105

Suzuki S, Furuya K, Kawai T, Takeuchi I (2008) Effect of seawater temperature on the productivity of Laminaria japonica in the Uwa Sea, southern Japan. J Appl Phycol 20:833-844

Svendsen H, Beszczynska-Møller A, Hagen JO, Lefauconnier B, Tverberg V, Gerland S, Ørbæk JB, Bischof K, Papucci C, Zajaczkowski M, Azzolini R, Bruland O, Wiencke C, Winther J-G, Dallmann W (2002) The physical environment of Kongsfjorden-Krossfjorden - an Arctic fjord system in Svalbard. Polar Res 21:133-166

Swanson AK, Druehl LD (2000) Differential meiospore size and tolerance of ultraviolet light stress within and among kelp species along a depth gradient. Mar Biol 136:657-664

Tait LW (2014) Impacts of natural and manipulated variations in temperature, $\mathrm{pH}$ and light on photosynthetic parameters of coralline-kelp assemblages. J Exp Mar Biol Ecol 454:1-8

Taylor AR, Brownlee C, Wheeler GL (2012) Proton channels in algae: reasons to be excited. Trends Plant Sci 17:675-684

tom Dieck I (1992) North Pacific and North Atlantic digitate Laminaria species (Phaeophyta): hybridization experiments and temperature responses. Phycologia 31:147-163

tom Dieck I (1993) Temperature tolerance and survival in darkness of kelp gametophytes (Laminariales, Phaeophyta)- ecological and biogeographic implications. Mar Ecol Prog Ser 100:253-264

Voerman SE, Llera E, Rico JM (2013) Climate driven changes in subtidal kelp forest communities in NW Spain. Mar Environ Res 90:119-127

Wang WJ, Wang FJ, Sun XT, Liu FL, Liang ZR (2013) Comparison of transcriptome under red and blue light culture of Saccharina japonica (Phaeophyceae). Planta 237:1123-1133

Weslawski JM, Wiktor J, Kotwicki L (2010) Increase in biodiversity in the Arctic rocky littoral, Sorkappland, Svalbard, after 20 years of climate warming. Mar Biodivers 40:123-130

Weslawski JM, Kendall MA, Wlodarska-Kowalczuk M, Iken K, Kedra M, Legezynska J, Sejr MK (2011) Climate change effects on Arctic fjord and coastal macrobenthic diversity - observations and predictions. Mar Biodivers 41:71-85

Wessels H, Hagen W, Molis M, Wiencke C, Karsten U (2006) Intra- and interspecific differences in palatability of Arctic macroalgae from Kongsfjorden (Spitzbergen) for two benthic sympatric invertebrates. J Exp Mar Biol Ecol 329:20-33

Widmann C, Gibson S, Jarpe MB Johnson GL (1999) Mitogen-activated protein kinase: conservation of a three-kinase module from yeast to human. Physiol Rev 79:143-180

Wiencke C, Amsler CD (2012) Seaweeds and their communities in polar regions. In: Wiencke C, Bischof K (eds) Advances in seaweed biology. Novel insights into ecophysiology, ecology and utilization, Ecological studies, vol 219. Springer, Berlin/Heidelberg, pp 265-291

Wiencke C, Bischof K (eds) (2012) Seaweed biology. Novel insights into ecophysiology, ecology and utilization. Ecological studies Vol 219, Springer Publishers, 518 pp

Wiencke C, Fischer G (1990) Growth and stable carbon isotope composition of cold-water macroalgae in relation to light and temperature. Mar Ecol Prog Ser 65:283-292

Wiencke C, Bartsch I, Bischoff B, Peters AF, Breeman AM (1994) Temperature requirements and biogeography of Antarctic, Arctic and amphiequatorial seaweeds. Bot Mar 37:247-259

Wiencke C, Gómez I, Pakker H, Flores-Moya A, Altamirano M, Hanelt D, Bischof K, Figueroa FL (2000) Impact of UV radiation on viability, photosynthetic characteristics and DNA of brown algal zoospores: implications for depth zonation. Mar Ecol Prog Ser 197:217-229

Wiencke C, Clayton MN, Schoenwaelder M (2004) Sensitivity and acclimation to UV radiation of zoospores from five species of Laminariales from the Arctic. Mar Biol 145:31-39

Wiencke C, Roleda M, Gruber A, Clayton M, Bischof K (2006) Susceptibility of zoospores to UV radiation determines upper depth distribution limit of Arctic kelps: evidence through field experiments. J Ecol 94:455-463 
Wiencke C, Lüder UH, Roleda MY (2007) Impact of ultraviolet radiation on physiology and development of zoospores of the brown alga Alaria esculenta from Spitsbergen. Physiol Plant 130:601-612

Wiencke C, Gómez I, Dunton KH (2009) Phenology and seasonal physiological performance of polar seaweeds. Bot Mar:585-592

Wlodarska-Kowalczuk M, Pearson TH, Kendall MA (2005) Benthic response to chronic natural physical disturbance by glacial sedimentation in an Arctic fjord. Mar Ecol Prog Ser 303:31-41

Włodarska-Kowalczuk M, Kukliński P, Ronowicz M, Legeżyńska J, Gromisz S (2009) Assessing species richness of macrofauna associated with macroalgae in Arctic kelp forests (Hornsund, Svalbard). Polar Biol 32:897-905

Wu S, Sun J, Chi S, Wang L, Wang X, Liu C, Li X, Yin J, Liu T, Yu J (2014) Transcriptome sequencing of essential marine brown and red algal species in China and its significance in algal biology and phylogeny. Acta Oceanol Sin 33:1-12

Wulff A, Iken K, Quartino ML, Al-Handal A, Wiencke C, Clayton MN (2009) Biodiversity, biogeography and zonation of marine benthic micro- and macroalgae in the Arctic and Antarctic. Bot Mar 52:491-508

Young IR, Zieger S, Babanin AV (2011) Global trends in wind speed and wave height. Science 332:451-455 